\title{
Venus flytrap (Dionaea muscipula Solander ex Ellis) contains powerful compounds that prevent and
}

\section{cure cancer}

\author{
François Gaascht ${ }^{1}$, Mario Dicato ${ }^{1}$ and Marc Diederich ${ }^{2}{ }^{*}$ \\ 1 Laboratory for Molecular and Cellular Biology of Cancer (LBMCC), Hôpital Kirchberg, Luxembourg, Luxembourg \\ 2 Department of Pharmacy, College of Pharmacy, Seoul National University, Seoul, South Korea
}

Edited by:

Zigang Dong, University of

Minnesota, USA

\section{Reviewed by:}

Arturo Sala, Brunel University, UK, UCL Institute of Child Health, UK David Engelberg, The Hebrew

University of Jerusalem, Israel

\section{*Correspondence:}

Marc Diederich, Department of

Pharmacy, College of Pharmacy,

Seoul National University, Seoul

151-742, South Korea

e-mail:marcdiederich@snu.ac.kr
Chemoprevention uses natural or synthetic molecules without toxic effects to prevent and/or block emergence and development of diseases including cancer. Many of these natural molecules modulate mitogenic signals involved in cell survival, apoptosis, cell cycle regulation, angiogenesis, or on processes involved in the development of metastases occur naturally, especially in fruits and vegetables bur also in non-comestible plants. Carnivorous plants including the Venus flytrap (Dionaea muscipula Solander ex Ellis) are much less investigated, but appear to contain a wealth of potent bioactive secondary metabolites. Aim of this review is to give insight into molecular mechanisms triggered by compounds isolated from these interesting plants with either therapeutic or chemopreventive potential.

Keywords: chemoprevention, therapy, natural compound, Dionaea

\section{INTRODUCTION}

Natural products derived from plants, animals, and microorganisms have traditionally been the main source of active medicinal compounds without a deep understanding of their mechanism of action. Emergence of resistance in different already known pathologies (cancer, bacterial infections) $(1,2)$, but also the emergence of other, yet incurable diseases (Alzheimer's disease, Parkinson's disease, AIDS ...) (3), call for the discovery of novel therapeutic compounds and the improvement of efficiency of already known molecules $(4,5)$.

The term "secondary metabolites" refers to molecules, which are not directly involved in essential processes like development, growth, and reproduction compared to the primary metabolism. Synthesized by all living kingdoms (Archae, Bacteria, Protisae, Plantae, Fungi, and Animalia), these non-essential metabolites are different depending on the species and are classified according to their method of synthesis. Structurally highly diversified and complex and present in very small quantities, secondary metabolites account for often less than $1 \%$ of the total mass of organic carbon in the organism. Their level of synthesis can also depend on the physiological and the developmental stage of the organism but also environmental factors like the soil, climate, or weather. Synthesis of secondary metabolites can be induced after stimulation by stressors from diverse origins. Originally isolated from plants, recent researches have shown that some secondary metabolites are synthesized by symbiotic organisms like bacteria and not by the host organisms themselves and that other have symbiotic origins. The role of secondary metabolites is to ensure the survival of the organism in its environment. Some allow organisms to protect themselves against predators or herbivores, insects, pathogens but also to kill preys like snake and arthropod venoms or against other organisms for access to resources (light, water, and nutrients). Other metabolites can help to resist environmental stress (drought, nutrient deficiencies), attract pollinating insects (by color and odor), or to ensure symbiosis with other organisms. To date, more than 200,000 different secondary metabolites have been discovered and described. Some have been diverted from their original use by human and are now used in commercial preparations such as dyes, drugs, or insecticides (6-12).

\section{"NON-FOOD" PLANTS ARE ALSO AN ATTRACTIVE SOURCE OF MOLECULES WITH POTENTIAL CHEMOPREVENTIVE INTEREST}

Various chemopreventive and therapeutic compounds have been isolated from food plants. We can notably mention, flavonoids (carrots) including chalcones, isothiocyanates (cabbage), lycopene (tomatoes), indoles, organosulfides (garlic), and polyphenols (curcumin) (13-19).

Many compounds can also be found in food preparations made with fruits or vegetables like resveratrol from red wine (20-22) or catechins and procyanidins and polyphenols from cocoa $(23,24)$ or quercetin and kaempferol from honey (25).

However, many "non-food" plants from all around the World are also attractive sources for molecules with potential chemopreventive interests (26-29).

The underwater world is also rich in bioactive molecules with chemopreventive and anti-tumor potential. Among these secondary metabolites discovered in animal, fungi, micro-organism, or marine plants we can mention, for example heteronemin and hemiasterlin (sponges), kahalalide F. (sea slug), naphthopyrones (echinoderm), didemnin B (tunicate), and amphidinolides (algae) $(12,18,30-34)$.

\section{THE VENUS FLYTRAP (DIONAEA MUSCIPULA SOLANDER EX ELLIS)}

Different populations used carnivorous plants for hundreds of years in traditional medicine all around the World. In Europe 
and North America, butterworts (Pinguicula vulgaris, Pinguicula alpina) were used for the treatment of wounds. Decoctions of butterworts and sundew (Drosera rotundifolia) were administered for their expectorant and antitussive properties to people with respiratory diseases like pertussis, bronchitis, and asthma but also to treat stomach pain and tuberculosis. Magic properties of sundews were also used for their aphrodisiac effects and their ability to promote delivery. Today this type of plant is used by the modern pharmaceutical industry in the preparation of syrups to treat coughs. The fresh juice secreted by the leaves of sundew is used for local application on warts or bunions (35-38).

In North America, roots and leaves of the purple pitcher plant Sarracenia purpurea were used by the endogenous population for its diuretic and laxative properties and also to treat fever, cough, and diabetes. The plant was also used to treat other infectious diseases like scarlet fever, smallpox, and measles. Plant decoctions were also prescribed to pregnant women to ease labor, to prevent sickness after childbirth and to treat absence of menstrual cycle (35-37, 39, 40).

In South-East Asia and in India, natives from local tribes used the pitcher plant Nepenthes khasiana as medical plant. They used juice of young flowers and of unopened pitchers or crushed pitcher powder to treat stomach pain and eye troubles (pain, cataract, night blindness), urinary troubles but also skin diseases. Preparations were also given to malaria, leprosy, and cholera patients (41-46).

The Venus flytrap (D. muscipula Solander ex Ellis), the only species of the genus Dionaea, is a carnivorous plant that grows in marshy areas of North and South Carolina states of the United States (Figure 1). To survive in these environments that are poor in nutrients, it has developed active traps to catch small prey (insects, spiders) that serve as an additional source of nutrients. The plant catches its prey with nectar produced by glands localized at the inner side of the trap and exposing an UV pattern. When the animal touches a sensitive trigger hair, a movement of ions is generated, producing an osmotic gradient that changes the size and shape of specialized cells of the trap that result in trap closure (4749). Once the trap closes on the prey, other glands, also localized at the inner part of the trap, secrete a digestive acid liquid containing a number of enzymes (proteases, nucleases, phosphatases, and amylases) for digestion of the prey (50). Nutrients are released and then reabsorbed by the plant through both digestive glands and by endocytosis (51-53).

\section{SECONDARY METABOLITES OF DIONAEA MUSCIPULA}

Dionaea muscipula was also the subject of modern biomedical research. The analysis of the various different secondary metabolites (naphthoquinones, flavonoids, phenolic acids) isolated from the plant and identified (Table 1; Figure 2) revealed that they possess different interesting therapeutic properties (54-58).

\section{NAPHTHOQUINONES}

These pigment molecules are widespread in plants, lichens, fungi, and microorganisms and these molecules derive from the phenol synthesis pathway. In plants, they act as bactericide, insecticide, fungicide, and allelopathic agents (substances that promote or impede the growth of surrounding organisms) $(70,135,136)$.

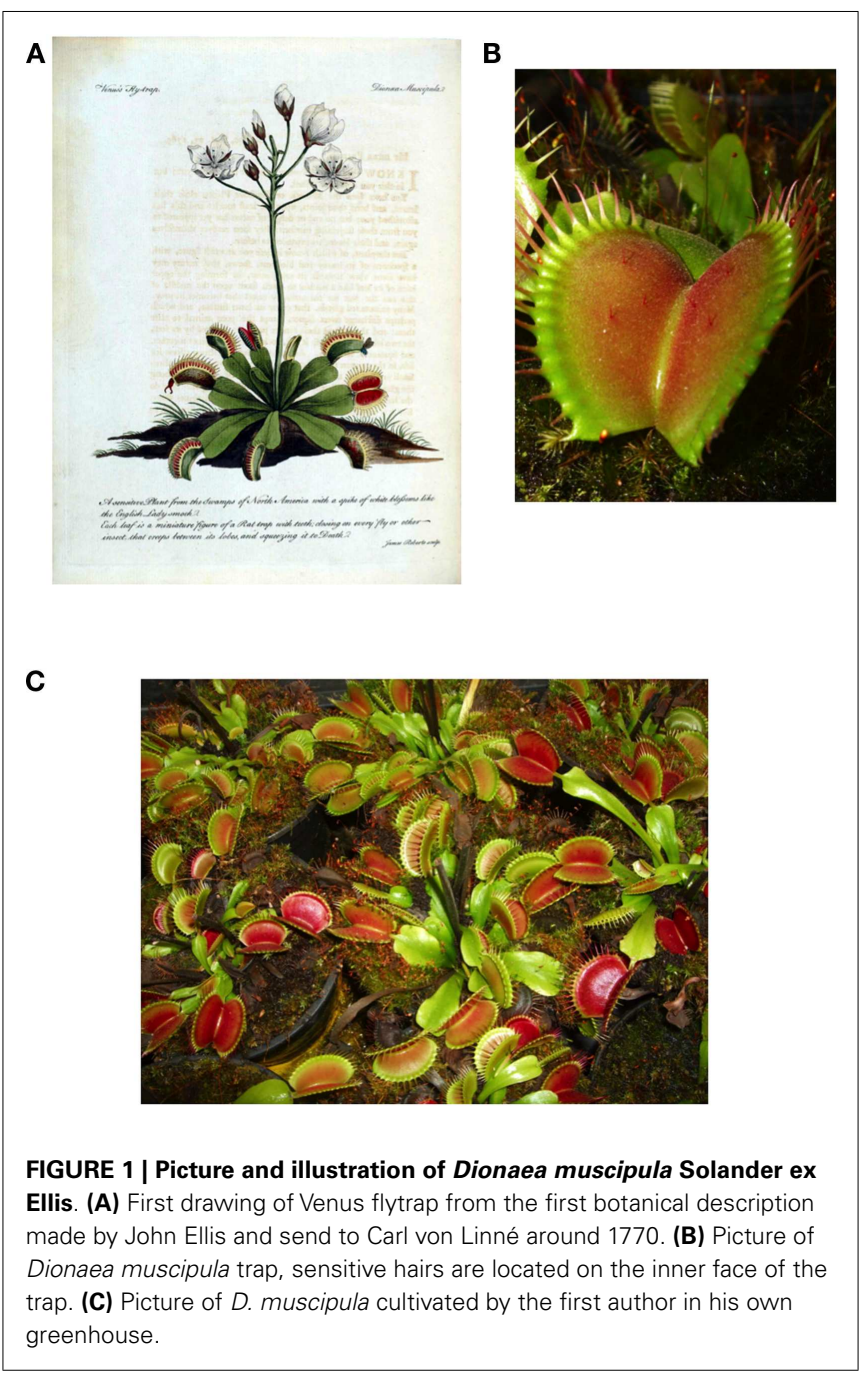

\section{Plumbagin}

Plumbagin (Figure 2) is a yellow naphthoquinone with antibacterial, anti-fungal, anti-inflammatory, and anti-cancer properties. This molecule gets its name from the plant in which it was discovered, Plumbago zeylanica (59) but is very common and is present in others plants like Limonium axillare or walnut trees (Juglans sp.) (60-63) but also in other carnivorous plants like $N$. khasiana, Nepenthes gracilis, or Drosera binata $(64,137,138)$. The roots of $P$. zeylanica were already used for centuries in Indian traditional medicine for their cardiotonic, neuroprotective, and hepatoprotective properties (139). In the Venus flytrap, plumbagin provides a protective role against predators and parasites (58).

Capable to generate reactive oxygen species (ROS) and to induce DNA cleavage, plumbagin inhibits topoisomerase II in HL-60 cells (65). It also has a cytotoxic effect on A549 cells and is described as being able to disrupt the microtubular network by interacting directly with tubulin (66). This particular naphthoquinone is known to be an inhibitor of the activated NF-кB (Nuclear Factor kappa B) signaling pathway induced by carcinogens, inflammatory stimuli and TNF- $\alpha$ (Tumor Necrosis Factor alpha). It blocks the expression of anti-apoptotic genes 


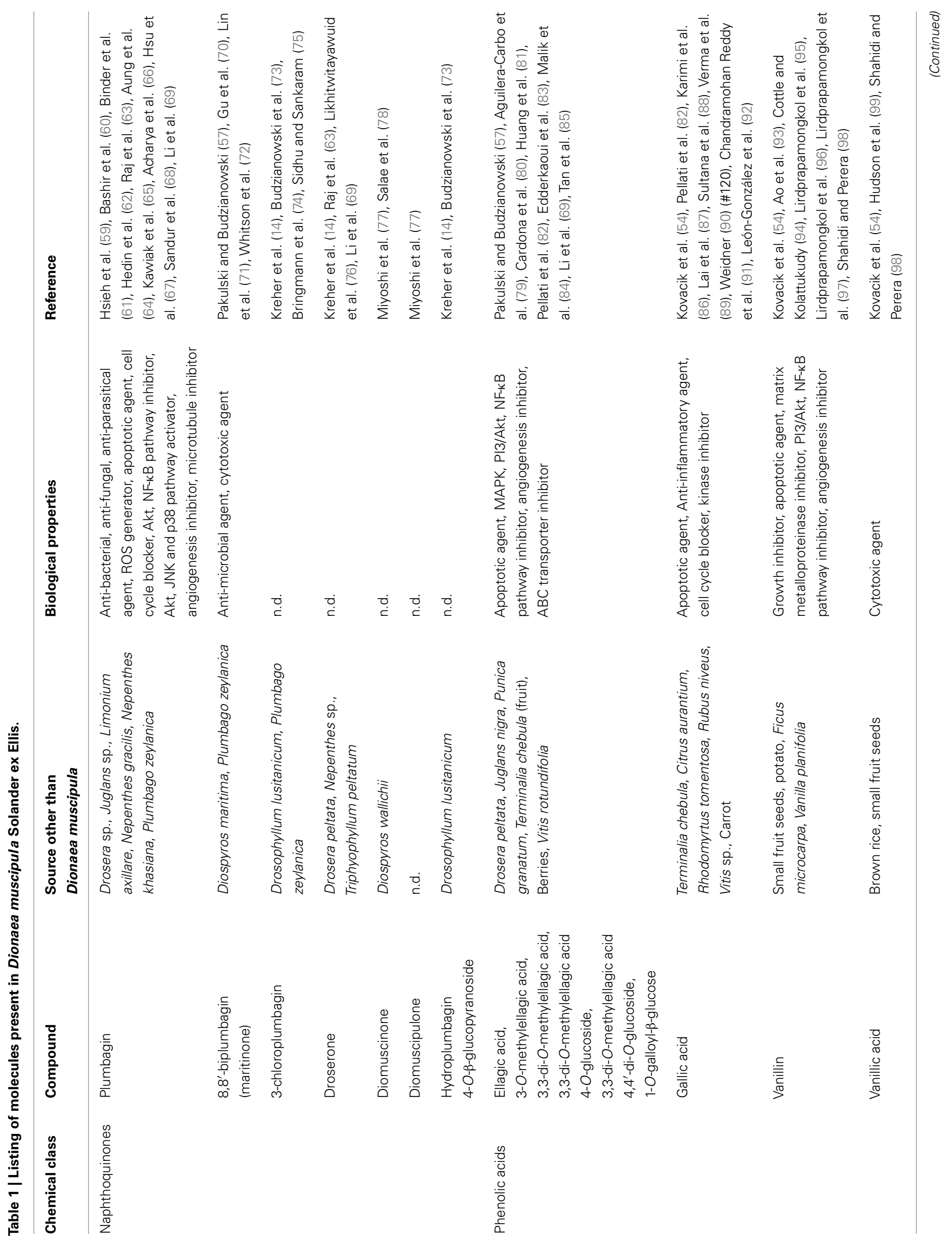




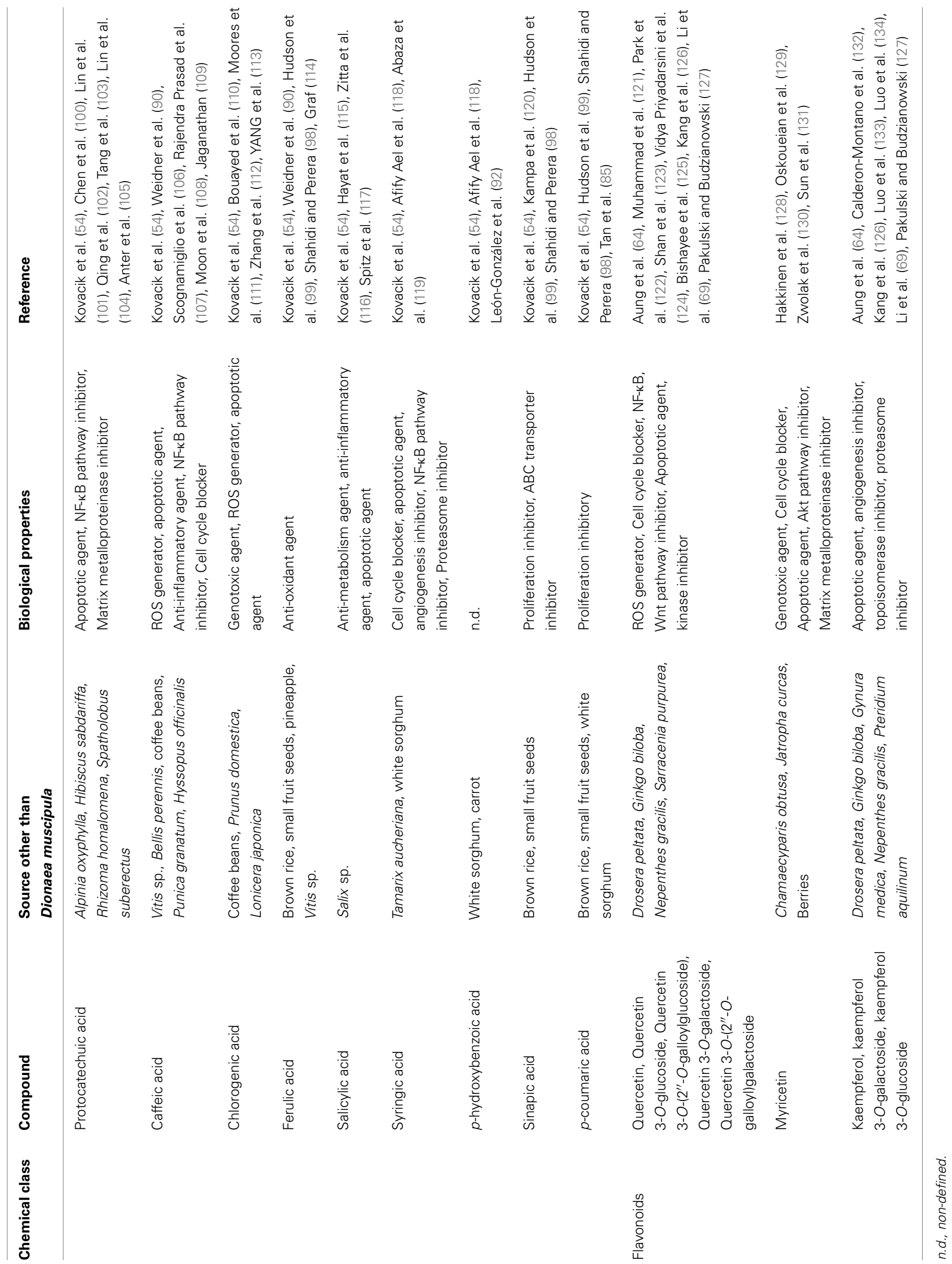



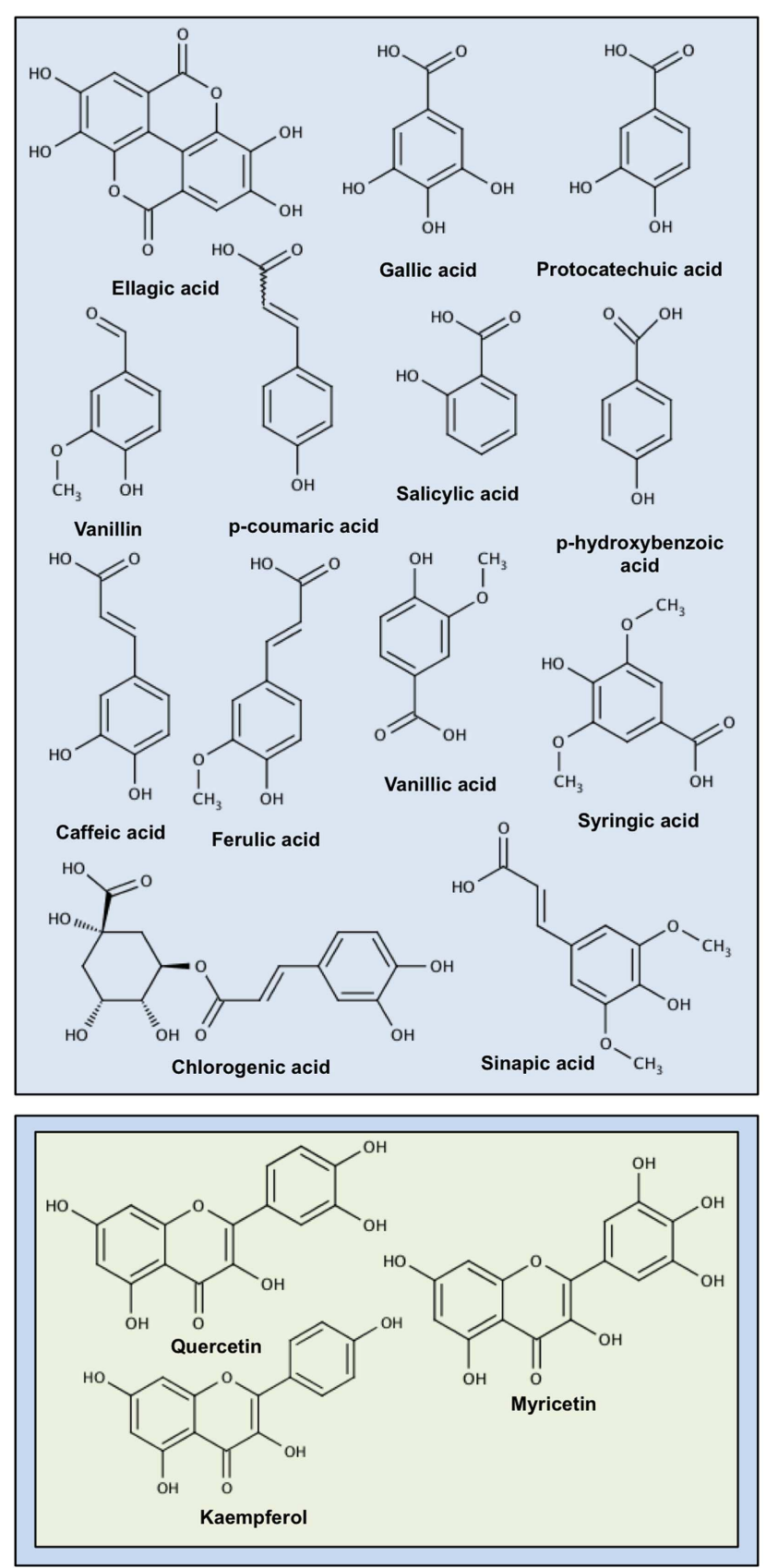

FIGURE 2 | Continued

including Bcl-2, Bcl-xL, and surviving and genes regulating cell proliferation (cyclin D1) and angiogenesis like Matrix metalloproteinase 9 (MMP-9) or Vascular endothelial growth factor (VEGF). It thus leads to cell cycle arrest at the G2/M phase transition and an increase of the TNF-induced apoptosis $(67,68)$. Described as an Akt pathway inhibitor, it also blocks the activity of GSK-3 $\beta$ (Glycogensynthase kinase 3 beta) protein kinase in human breast cancer cell lines MCF-7 and MDA-MB-231 (140). In human melanoma A375.S2 cells, it induces cell cycle

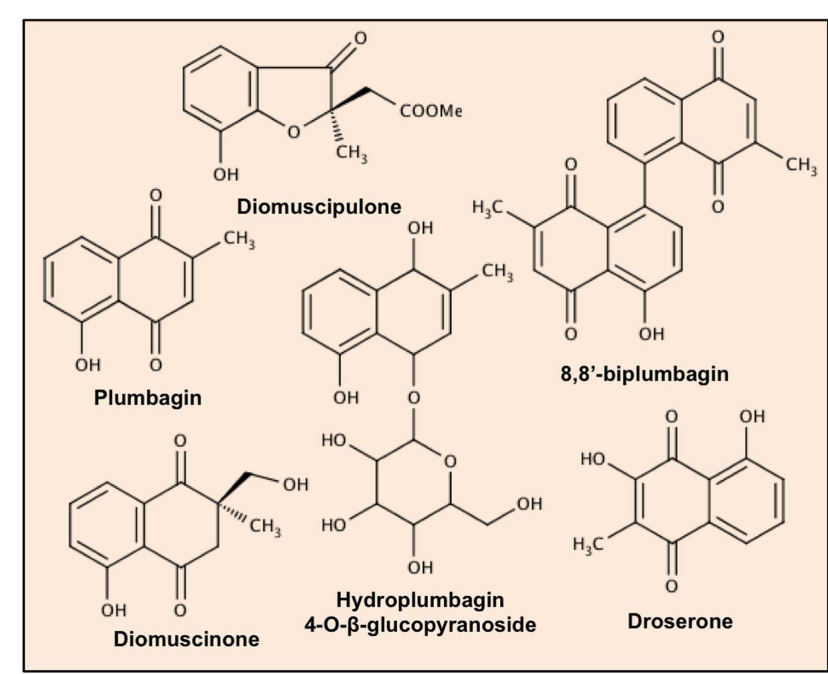

FIGURE 2 | Chemical structures of molecules present in Dionaea muscipula Solander ex Ellis. Compounds are arranged according to the following classification: phenolic compounds in blue, flavonoids in green, and naphthoquinones in orange.

arrest in G2/M, which leads to apoptosis. The mechanistic analysis showed that plumbagin activates JNK (c-jun-N-terminal kinase) and ERK (Extracellular signal-regulated protein kinase) $1 / 2$ but had no effect on p38 (141). In H460 lung cancer cells, plumbagin increases the expression of p53 and p21, which leads to cell cycle arrest in G2/M and triggers death by apoptosis. In addition, the authors showed that naphthoquinone activates both JNK and p38 but at the same time inhibits the activity of Akt (142). However in another study, plumbagin has been shown to activate both Akt and ERK 1/2 in healthy pre-adipocyte 3T3L1 mouse cells (143). In vivo experiments performed on mice have shown that plumbagin inhibits the growth of tumors and the number of metastasis by an inhibition of the expression of several markers like MMP-9, 2, and VEGF in ovarian and prostate-cancer cells $(144,145)$. Due to its structure, plumbagin is also known as a ROS generator. In MCF-7 cells, increased ROS accompanies a decrease of cell viability. Analysis of the mechanism triggered by ROS suggests that plumbagin inhibits 1 , 4-phosphatidylinositol 5-kinase (PI5K) expression. In K562 cells, naphthoquinone up-regulates the membrane level of death receptors (DRs) DR4 and DR5, which results in a higher sensitivity to TRAIL (TNF-related apoptosis-inducing ligand) and a reduction of cell viability. Results obtained by molecular docking showed that plumbagin docks into the receptor ligand site of Tumor Necrosis Factor-Related Apoptosis-Inducing Ligand (TRAIL)-DR 5 complex that contributes to explain triggering of apoptosis via the extrinsic pathway (146-149). Plumbagin is also known to act as an inhibitor of multidrug resistance-linked ATP-binding cassette drug transporter ABCG2, a protein responsible for the drug efflux in cancer cells (150). Ex vivo and in vitro experiments showed that plumbagin inhibits microtubule polymerization by direct binding to tubulin at the colchicine binding site (66). Pharmacokinetic studies have shown that plumbagin has an oral 
bioavailability of about $40 \%$ in conscious freely moving rat models and that plumbagin is detected in a micromolar range $1 \mathrm{~h}$ after administration (151).

\section{Plumbagin derivatives}

Some others plumbagin derived molecules have also been isolated from $D$. muscipula by several groups. A plumbagin-dimer, $8,8^{\prime}$ biplumbagin also called maritinone (Figure 2) have also been isolated from the carnivorous plant (57) but also from other plants like P. zeylanica or Malaysian persimmon (Diospyros maritima) $(71,72)$. Tested for its potent anti-tumoral effect on $\mathrm{KB}$, LNCaP, Lu1, K562, Raji, Jurkat, Vero, Calu-1, HeLa, and Wish cancer cell lines, maritinone has shown strong effects on the proliferation of these cells $(70,71)$. Identified in other plants than D. muscipula like Malaysian persimmon (Diospyros maritime) and carnivorous plants Nepenthes sp., and Drosophyllum lusitanicum $(73,76,137,152)$ and isolated by Kreher et al. droserone (Figure 2), 3-chloroplumbagin (Figure 2), and hydroplumbagin 4-O- $\beta$-glucopyranoside (Figure 2) (14) have not yet been studied for their biological effects. Miyoshi et al. reported the isolation of two other naphthoquinones, diomuscinone (Figure 2), and diomuscipulone (Figure 2) together with plumbagin from roots of Venus flytrap (77). Recently, diomuscinone has been isolated from Diospyros wallichii (78) but none of these three compounds have been tested to elucidate their biological effects out of the plant.

\section{PHENOLIC ACIDS}

The term "phenolic" or "polyphenol" is chemically defined as a molecule, which possesses at least one aromatic ring (phenol) or several (polyphenol) hydroxyl substituents. They have many roles in plants like UV sunscreens, messengers, pigments, plant growth factors and protection against fungi, bacteria, insects, and nematodes (153).

\section{Ellagic acid}

Ellagic acid (Figure 2) is a polyphenolic molecule synthesized by Venus flytrap and many other plants such as pomegranate (Punica granatum), Terminalia chebula fruit (yellow myrobalan), berry fruits (blueberry, blackberry, and strawberry), Vitis rotundifolia (Muscadine grapevine), or black walnut (Juglans nigra) (57, 79-82).

By their astringent taste, ellagic acid, and other tannins play a role in plant defense against herbivores and pests as digestibilityreducing compounds $(154,155)$ but also as anti-bacterial agent $(156,157)$.

It is a chemopreventive agent that reduces cell proliferation, inhibits NF- $\mathrm{B}$ by interfering with the binding of this transcription factor to DNA. The compound triggers apoptosis of pancreatic cancer cells by cytochrome $c$ release and activation of caspase-3 (83). Ellagic acid decreases human prostate carcinoma PC3 cells cell growth and viability in a dose-dependent manner and triggers apoptosis. Authors observed poly(ADP-ribose) polymerase (PARP)-1 cleavage, decrease of anti-apoptotic Bcl-2 protein and increase of pro-apoptotic Bax protein and activation of caspase-3, 6, 8, and 9. Pre-treatment with pan-caspase inhibitor (Z-VAD-FMK) has confirmed the caspase-dependent apoptosis induced by ellagic acid (84). In vivo experiments performed on rat models with inducible colon cancer have shown that ellagic acid reduces expression of NF-кB, COX-2 (Cyclooxygenase-2), iNOS (inducible nitric oxide synthase), TNF- $\alpha$, and IL-6 (158). Using human breast cancer MDA-MB-231 cells and human umbilical vein endothelial cells (HUVEC), Wang et al. have shown that ellagic acid inhibits proliferation, migration, and endothelial cell tube formation. Inhibiting VEGFR-2 tyrosine kinase activity and the downstream signaling pathways including MAPK (Mitogen-activated protein kinase) and PI3K (Phosphatidylinositide 3-kinases)/Akt, ellagic acid decreases MDA-MB-231 breast cancer xenograft growth and p-VEGFR-2 expression. Further in silico molecular docking simulations showed that ellagic acid could bind within the ATP-binding region of the VEGFR-2 kinase unit (159).

\section{Gallic acid}

Gallic acid (Figure 2) has been isolated from bitter orange tree flowers (Citrus aurantium), Marrubium persicum, yellow myrobalan fruit (T. chebula), Acalypha australis, Pleurotus sp., Vitis sp. seeds, rose myrtle (Rhodomyrtus tomentosa), Mysore raspberry (Rubus niveus), white sorghum, or carrot (82, 86-88, 90, 118, 160-162).

This tannin that can be released by the aerial parts of the plant is a nematicide but possesses also anti-bacterial and anti-fungal properties $(88,163,164)$.

Described in many papers as an anti-cancer agent that can affect many cellular targets (89), gallic acid induces cell cycle arrest in G0/G1 in human leukemia K562 cells by down-regulating cyclin $\mathrm{D}$ and $\mathrm{E}$ levels. Gallic acid induces cell death by apoptosis in K562 leading to PARP-1 cleavage, cytochrome $c$ release, and caspase activation. Expression of COX-2, a molecule involved in cancerrelated inflammation and progression, is also reduced by gallic acid treatment. Furthermore, this phenolic acid inhibits BCR/ABL tyrosine kinase and NF- $\kappa$ B pathway activity (91). Moreover, this vegetable tannin blocks Akt/small GTPase and NF-кB pathway activity in human gastric carcinoma AGS cell line and inhibits cellular migration via the expression of RhoB. Results have been confirmed in nude mice models where gallic acid treatment leads to decreased development of metastasis (165). In vivo experiments using a mouse prostate TRAMP model fed with gallic acid showed inhibition of prostate-cancer growth and progression. Westernblot analysis performed on mice prostate tissues revealed decreased cdc2, Cdk2, Cdk4, and Cdk6 expression as well as a reduction of the proteins cyclin B1 and E (166). Two human osteosarcoma cell lines $\mathrm{U}-2 \mathrm{OS}$ and MNNG/HOS treated with gallic acid allowed demonstrating inhibition of cell proliferation and induction of apoptotic cell death. Results show that gallic acid increases p38 and ERK 1/2 activation and decreases of JNK. Moreover, pre-treatment with a p38 inhibitor prevents gallic acid-induced growth inhibition but not ERK $1 / 2$ and JNK inhibitors that promotes proliferation. Inhibition of tumor growth is confirmed by in vivo experiments in a dose-dependent manner in nude $\mathrm{BALB} / \mathrm{c}$ mice. Immunohistochemistry shows a decrease of PCNA (Proliferating Cell Nuclear Antigen) and CD31 expression in MNNG/HOS tumor tissues (167). Pharmacokinetic studies have shown that gallic acid is rapidly absorbed by the organism, metabolized in different forms after $2 \mathrm{~h}$, and are detected at a micromolar range in plasma, a 
concentration lower than the concentration used for several biological studies. A study conducted on black tea drinkers showed that after $3 \mathrm{~h}$, the organism eliminates nine different metabolized forms of gallic acid via the urinary tract $(168,169)$.

\section{Vanillin}

Vanillin (Figure 2) is probably one of the most famous flavor molecules and the most used widely used by food, chemical and perfume industries. Isolated in 1858 by Gobley as the main flavor constituent of vanilla (Vanilla planifolia), but also present in other plants (potatoes, Ficus microcarpa) $(83,93,94)$, vanillin is today mainly synthesized or produced by chemical or biotechnological methods using fungi or bacteria (170-173). In addition to being a flavor molecule, vanillin exerts anti-fungal, and anti-bacterial properties $(174,175)$.

At non-toxic concentrations, vanillin inhibits growth of mammary adenocarcinoma cell line 4T1 but also decreases MMP-9 activity and thus reduces cell migration and invasion. In vivo experiments performed on 4T1 mammary adenocarcinoma cells injected in $\mathrm{BALB} / \mathrm{c}$ mice have shown that vanillin strongly reduces the number of lung metastasis colonies. Similar experiments performed with vanillic acid were not conclusive (95). Further experiments performed by the same group have shown that vanillin pre-treatment of Hela cells blocks TRAIL - induced phosphorylation of subunit p65 and transcriptional activity of NF- $\kappa$ B pathway and stimulates TRAIL-induced cell death through the extrinsic apoptosis pathway (96). Vanillin also inhibits cell migration of human lung cancer cells induced by hepatocyte growth factor (HGF). It prevents Akt phosphorylation but has no effect on Met and ERK phosphorylation and inhibits phosphatidylinositol 3-kinase (PI3K). Chick chorioallantoic membrane assays showed that vanillin inhibits also angiogenesis (97). Vanillin induces apoptosis in HT-29 human colorectal cancer cell line and NIH/3T3 normal cell lines with a concentration of 400 and $1000 \mu \mathrm{g} / \mathrm{mL}$, respectively. Flow cytometry analysis showed that a low concentration of vanillin induce cell cycle arrest in G0/G1 phase whereas a high concentration stops cells in G2/M phase (176). Pharmacokinetic studies on rat models demonstrated that vanillin has a relatively good bioavailability $(7.6 \%)$. Others studies have revealed that $24 \mathrm{~h}$ after ingestion, vanillin is mainly metabolized as glucuronide and sulfate conjugates and that after $48 \mathrm{~h}, 94 \%$ of the initial dose of vanillin is found under different forms, including vanillin itself $(7 \%)(177,178)$.

\section{Protocatechuic acid}

Described by many articles as therapeutic molecules active against several diseases, protocatechuic acid (Figure 2) was identified in plants like True roselle (Hibiscus sabdariffa), Rhizoma homalomenae, Spatholobus suberectus, and Alpinia oxyphylla (100-103, 179).

Protocatechuic acid inhibits AGS (human stomach adenocarcinoma) cell migration and proliferation at non-toxic concentrations. It can also inhibit the NF- $\kappa \mathrm{B}$ pathway and both MMP2 expression and activity by modulating RhoB/protein kinase $\mathrm{C} \varepsilon(\mathrm{PKC} \varepsilon)$ and Ras/Akt cascade pathways. Using in vivo mice models (B16/F10 melanoma cells), anti-metastasis proliferation of protocatechuic acid has been confirmed (104). Phenolic acid induces cell death of HepG2 hepatocellular carcinoma cells and stimulates c-Jun N-terminal kinase (JNK) and p38. Further experiments have shown that pre-treatment of HepG2 with $\mathrm{N}$-acetylL-cysteine (NAC) blocks the cytotoxic effect of protocatechuic acid (180). Protocatechuic acid doesn't exert genotoxic effects toward Drosophila melanogaster wing spot assay. However it shows antigenotoxic effects against hydrogen peroxide inhibits tumoricidal activity and moreover triggers cell death by apoptosis in HL-60 leukemia cells (105).

\section{Caffeic acid}

Present in Vitis sp. seeds, pomegranate (P. granatum), coffee beans, honey, common daisy (Bellis perennis), and hyssop (Hyssopus officinalis), caffeic acid (Figure 2) is a secondary metabolite that exerts anti-bacterial and anti-fungal properties $(90,106,181,182)$.

Caffeic acid is a ROS generator inducing oxidative DNA damage and alters mitochondrial membrane potential in HT-1080 human fibrosarcoma cells. It stimulates lipid peroxidation and decreases activities of enzymatic anti-oxidants superoxide dismutase (SOD), catalase (CAT), as well as glutathione peroxidase (GPx), and glutathione (GSH) levels. Observations by fluorescence microscopy showed that caffeic acid induces cell death by apoptosis (107). This molecule is known to act as an inhibitor of DNA methylation due to its ability to inhibit human DNA methyltransferase 1 (DNMT1) and to partially inhibit retinoic acid receptor (RAR) b promoter in MCF-7 and MAD-MB-231 cells (183). Caffeic acid is an antiinflammatory agent by decreasing expression of IL- 8 and NF- $\mathrm{B}$ pathway activity by triggering TNF-alpha-induced I $\kappa$ B degradation that lead to a reduction of NF- $\kappa \mathrm{B}$ target genes expression which are regularly involved into carcinogenesis (108). Caffeic acid decreases HCT 15 colon cancer cells in a time dependent manner. It induces cell cycle arrest that leads to accumulation of cells in sub-G1. Inducing also ROS production and reduction of the mitochondrial membrane potential, flow cytometry analysis confirmed cell death by apoptosis (109). Among several small phenolic acids tested for their anti-proliferative effect on T47D human breast cancer cells, caffeic acid exerts is most potent. Further experiments showed that all compounds induce apoptosis via the Fas/FasL pathway and that caffeic acid is able to inhibit aryl hydrocarbon receptor-induced CYP1A1 gene expression (120). However it is important to underline that chlorogenic acid (Figure 2), a caffeic acid analog and a Venus flytrap secondary metabolite, can be hydrolyzed to caffeic acid in the intestine and can be well absorbed by intestinal cells. In vitro and in vivo studies showed that in Caco-2 cells, caffeic acid exerts stronger anti-oxidant properties compared to chlorogenic acid. This differential efficiency can be explained by the fact that caffeic acid uptake is superior to chlorogenic acid uptake. Caffeic acid is a molecule known to be metabolized by intestinal bacteria, however studies have shown that caffeic acid can be detected in rat blood $6 \mathrm{~h}$ after ingestion together with different other metabolites. Another study demonstrated that $95 \%$ of caffeic acid is absorbed and that $11 \%$ of the ingested caffeic acid was excreted in urine (182, 184-187).

\section{Chlorogenic acid}

Chlorogenic acid (Figure 2) has been isolated from a huge diversity of plants like prune (Prunus domestica), japanese honeysuckle 
(Lonicera japonica), apple, plum, Eucommia ulmodies, and coffee beans (110-112, 188-190).

In plants, chlorogenic acid is a secondary metabolite involved in plant defense against pests, herbivores, fungi, or virus (191-194).

Human adenocarcinoma Caco- 2 cells treated with chlorogenic acid present a reduced proliferation rate and light microscopy observation reveals an abnormal morphology compared to untreated cells (195). Chlorogenic acid induces apoptosis by inducing ROS generation and reduces the mitochondrial membrane potential in U937 human leukemia cells. Further results obtained by Western-Blot show that chlorogenic acid promotes caspase- 3 activity and expression of caspase-3, 7, 8, and 9 in U937 cells (113). Chlorogenic acid can induce DNA damage in both normal lung MRC5 fibroblasts and A549 lung cancer cells and increases the levels of topoisomerase I- and topoisomerase II-DNA complexes in cells although cancer cells were the most sensitive to chlorogenic acid treatment (196). This compound also acts as an anti-oxidant reducing free radical DNA damages like DNA-single strand breaks $(110,197)$.

Chlorogenic acid has a very low bioavailability but is always present in the small intestine. It can only be detected in rat plasma with other metabolites in trace amounts $6 \mathrm{~h}$ after absorption. Another study has given the same result, chlorogenic acid has a rate of absorption of $33 \%$ and is detected only in trace amounts in rat urine. Studies showed that chlorogenic acid is not well absorbed by the organism compared to structurally related caffeic acid. Caffeic acid metabolism produces caffeic and ferulic acid, two other secondary metabolites of D. muscipula (184-186).

\section{Ferulic acid}

Ferulic acid (Figure 2) has been identified mainly in seeds like Vitis sp. seeds brown rice, but also wheat flour, pineapple, creosote bush (Larrea divaricata). Ferulic acid is an allelopathic agent that acts as seed germination inhibitor $(98,99,90,198-202,222)$.

Ferulic acid pre-treatment protects against $\gamma$-radiationinduced DNA damage in hepatocytes and significantly increases anti-oxidant enzymes, GSH, vitamins A, E, and C (203). In vivo studies have shown that mammary carcinogenesis induced in Sprague-Dawley rats fed with ferulic acid prevent tumor development in $80 \%$ of animals even if the exact protection mechanism remains unclear (204). Further animal experimentations on induced skin carcinogenesis mice model highlighted that oral ferulic acid administration completely prevented skin tumor formation but that topical application does not (205). Ferulic acid delayed cell cycle progression of Caco-2 colon cancer cells. cDNA microarrays showed that ferulic acid up-regulates centrosome assembly genes, such as RABGAP1 and CEP2 and S phase checkpoint protein SMC1L1 (206). Moreover, ferulic acid acts as an anti-oxidant that can reduce DNA strand breaks induced by $\gamma$ irradiation in peripheral blood leukocytes and bone marrow cells of mice. It promotes mice survival up to $6 \mathrm{~Gy}$ of $\gamma$-radiation (114, 207). Ferulic acid is absorbed by the intestine and can be detected in the blood of rat and human patients. Further studies showed that ferulic acid can be absorbed very quickly all along the gastrointestinal tract, can be detected in plasma already after $10 \mathrm{~min}$ and less than $1 \%$ of ingested ferulic acid can be found in rat feces. It can be metabolized under different forms including glucuronides, sulfates, and sulfoglucuronides conjugated forms, formed in the liver by different phase II enzymes reduce bioavailability (202, 208).

\section{Salicylic acid}

Already used by the Greeks and the Egyptians to treat aches and pains, this compound was initially isolated from willow tree bark by Buchner (Figure 2) in 1898. The isolated active principle was named from the Latin word "Salix" which means willow tree. Salicylic acid has been identified as the main metabolite of acetylsalicylic acid, the active principle of aspirin. Salicylic acid is a phytohormone that plays important roles in plant immune system, thermogenesis (heat production), root nodule formation but also more essential process like metabolism, flowering, and seed germination. Due to its important role, salicylic acid is found in almost all plants $(115,209-213)$.

Salicylic acid has no effect on CaCo-2 (colon carcinoma cells) proliferation under normoxic conditions but increases caspase-3/7 activities and increases phosphorylation of ERK $1 / 2$ under hypoxic conditions: salicylic acid increases caspase-3/7 activities but also decreases cell proliferation but has no effect on ERK 1/2 phosphorylation (116). In vitro assays have shown that salicylic acid reversibly inhibits 6-phosphofructo-1-kinase, an enzyme responsible for the glycolysis. It dissociates the quaternary structure of the enzyme into inactive dimers. Tested on MCF-7 cells, salicylic acid inhibits 6-phosphofructo-1-kinase that leads to a decreased cellular glucose consumption and viability (117). Anacardic acid, a derivative of salicylic acid and an inhibitor of histone acetyltransferase, is an anti-inflammatory compound like its precursor. It blocks the NF- $\kappa \mathrm{B}$ pathway by abrogation of phosphorylation and degradation of $\mathrm{I} \kappa \mathrm{B} \alpha$ and by inhibiting acetylation and nuclear translocation of its p65 subunit. Inhibition of the NF- $\kappa B$ pathway leads to down-regulation of target genes involved in cell proliferation (cyclin D1, COX-2), survival (Bcl-2, Bcl-xL), and invasion (MMP-9) $(213,214)$. Several clinical trials analyzed the effect of salicylic acid on colorectal cancer patients. Results show that a dose of $75 \mathrm{mg}$ of aspirin per day during several years reduces colorectal cancer incidence and mortality (215).

\section{FLAVONOIDS}

Flavonoids are secondary metabolites of the polyphenol family with a backbone composed of 15 carbon atoms organized into a common phenyl benzopyrone structure (C6-C3-C6). This group of molecules is divided into several sub-groups according to their chemical formulations including flavonols (quercetin, myricetin, and kaempferol), flavones, flavanones, flavanols, anthocyanins, dihydroflavonols, isoflavones, and chalcones. Their roles within plants are very diverse. Some have a protective role against UV, but also toward parasites, pathogens (insecticides, fungicides, vermicides) and herbivores. Other molecules act as signal molecules or help the plant to survive under stress conditions (drought period, nutrient-poor environment) (216).

\section{Quercetin}

Quercetin (Figure 2) is a molecule with anti-bacterial properties present in bitter orange tree flowers (Citrus aurantium), Epilebium species, Nepenthes gracilis, Leucaena leucocephala, S. purpurea, 
caper (Capparis spinosa), and chili peppers (Capsicum sp.) (64, $86,121,217-221)$. In plants, quercetin acts as a host defense molecule and a growth stimulatory agent, it is a nematode repellant, an anti-microbial agent, a root nodules inducer, an allelopathic agent, and a hyphal branching attractor for symbiotic fungus (223).

Concerning its biological properties as anti-cancer agent, quercetin has been the object of many studies (224). For example, this flavonol has been described as an anti-proliferative agent by inducing cell cycle arrest in G2/M and as an apoptotic agent due to its ability to inhibit the transcriptional activity of the Wingless pathway (Wnt) by reducing the amount of transcriptional coactivator $\beta$-catenin in the nucleus in SW480 colon cancer cells and by reducing the level of cyclin B1 and surviving $(122,123)$. In vitro experiments have shown that a concentration of $2 \mu \mathrm{M}$ of quercetin is sufficient to decrease $80 \%$ of the activity of 16 kinases, which are mostly involved in the control of mitotic processes (225). This secondary metabolite is also responsible for the induction of cell death by apoptosis of hepatocellular carcinoma cells after activation of caspases 3 and 9 (226). Quercetin used in combination with 5-fluorouracil (5-FU) on EC9706 and Eca109 esophageal cancer cells increased the cytotoxic effect and the percentage of apoptotic cells compared to quercetin or 5-iFU alone. These combined effects were explained by a decrease of $\mathrm{p}-\mathrm{I} \kappa \mathrm{B} \alpha$ expression induced by quercetin treatment (227). Quercetin is also known to induce cell cycle arrest in G2/M and to induce cell death in human HeLa cervical cancer cells by mitochondrial apoptosis through a p53-dependent mechanism. These results also showed that quercetin can inhibit the NF- $\kappa \mathrm{B}$ pathway by modulating the expression of NF- $\kappa \mathrm{B}$ p50 and p65, IKK $\beta$, p-IкB, and ubiquitin. Other results obtained by Western-blot have shown an increase of pro-apoptotic Bcl-2 family proteins (Bax, Bak, and Bad), an up-regulation of Apaf-1 and cytoplasmic cytochrome $c$ and a down-regulation of anti-apoptotic Bcl-2 family proteins (Bcl-2, Mcl-1) (124). Moreover Spagnuolo and collaborators demonstrated in addition, in U937 cells, a down-regulation of Mcl-1 by quercetin acting directly or indirectly on its mRNA stability and protein degradation (228). A study performed on HeLa cells showed that quercetin has the ability to interact with DNA and to generate ROS. This flavonol triggers a cell arrest in G2/M, followed by mitochondrial membrane depolarization, externalization of phosphatidyl-serine, release of cytochrome $c$ into the cytoplasm, decrease of Akt and Bcl-2 expression and cell death by apoptosis (125). A large Swedish population-based case-control study has shown that quercetin uptake decreases the risk to develop gastric adenocarcinoma. This protective effect was very strong for female smokers (229). Quercetin has been tested in several clinical trials on cancer patients. It has been tested in a chemoprevention purpose on 130 colon cancer patients treated with quercetin, rutin, or with sulindac (NCT00003365). Phase I clinical trials have shown that quercetin inhibits protein tyrosine phosphorylation in patient lymphocytes, is able to decrease CA-125 (Carbohydrate antigen 125) level in patients with ovarian cancer refractory to cisplatin and serum alpha-fetoprotein (AFP) levels in hepatocellular carcinoma patients (230). Quercetin is also actually undergoing clinical trials with genistein to evaluate their effects on prostate-specific antigen level on prostate-cancer patients (NCT01538316). Pharmacokinetic analysis performed on humans and rats have shown that quercetin has a very low bioavailability. In human, after an ingestion of about $87 \mathrm{mg}$ of quercetin, average plasma concentration is $344 \mathrm{nM}$ after $3 \mathrm{~h}$. Results have also shown that quercetin is no longer present in the aglycone, free form but is metabolized, and can only be detected as conjugated derivatives like quercetin glucuronides or quercetin 3-O-sulfate. However after further analysis Manach et al. showed that these quercetin derivatives maintain anti-oxidant activity although their effect were reduced to half of the quercetin (231-233). Sesink et al. showed that breast cancer resistance $A B C G 2$ and the multidrug resistance-associated protein 2 (Mrp2), two ATP-binding cassette (ABC) transporters involved in drug cancer resistance are able to pump both quercetin aglycone and quercetin conjugated derivatives out of the cells and thus explain the low bioavailability of quercetin (234).

\section{Myricetin}

Myricetin (Figure 2) is a quercetin analog present in many plants as for example Limonium axillare, Jatropha curcas, Japanese cypress (Chamaecyparis obtusa), Leucaena leucocephala, and many berries $(60,128,129,218,235)$. In plants, myricetin acts as a host defense molecule, is released by roots and acts as a nematode repellent and an inducer of root nodules in several cases (223).

This is a flavonol that exerts anti-bacterial (217) and anti-cancer properties which is able to inhibit mutagenesis induced by carcinogens such as benzo(a)pyrene (236). Myricetin is able to induce apoptosis of pancreatic cancer cells via the activation of caspase-3 and 9 (130). It induces apoptosis of human bladder carcinoma cell line T-24 with activation of caspase- 3 after DNA cleavage and cell cycle arrest in $\mathrm{G} 2 / \mathrm{M}$ phase by a down-regulation of cyclin B1 and cdc2. It inhibits the phosphorylation of Akt but increases the phosphorylation of $\mathrm{p} 38$ and decreases MMP-9 expression. In vivo experiments have shown a growth inhibition of T-24 xenografts on mice models (131). Myricetin is also able to induce apoptosis in HL-60 (human promyelocytic leukemia cells) through an ROS-independent cell death pathway (237). In vitro experiments have shown an inhibition of mammalian DNA polymerases and human DNA topoisomerase II by myricetin. Further experiments have revealed that it also inhibits proliferation of HCT-116 human colon carcinoma cells and trigger apoptosis after a cell cycle arrest in G2/M cell cycle transition (238). Recent studies have shown that a non-toxic dose of myricetin decreases PI3 kinase activity in pancreatic cancers cells MIA PaCa-2, Panc-1, or S2-013 and triggers cell death by apoptosis. In vivo experiments performed on mice have shown a regression of tumor growth and a decrease of metastasis (239). In rat models, myricetin is able to inhibit cytochrome P450 (CYP) activity in liver or intestine and thus to increase bioavailability of tamoxifen, a drug used to treat breast cancer. Similar results were observed for doxorubicin $(240,241)$.

\section{Kaempferol}

Kaempferol (Figure 2) is a flavonol identified in many plants like Nepenthes gracilis, chili peppers, Gynura medica, Bracken (Pteridium aquilinum), Ginkgo biloba (64, 126, 132, 219, 242, 243).

Involved into plant defense, kaempferol has been described as a nematode repellent, nematode egg hatching inhibitor, and allelopathic agent (223). 
From a therapeutic point of view, anti-cancer properties of kaempferol have been underlined by many papers $(132,244)$. A concentration of $40 \mu \mathrm{M}$ of kaempferol is sufficient to inhibit proliferation of oral cancer cell lines (SCC-1483, SCC-25, and SCC-QLL1). Analysis has shown PARP-cleavage and caspases-3dependent apoptosis (126). Kaempferol inhibits ovarian cancer cells and induces cell death by apoptosis in a dose-dependent manner. Luo et al. observed caspase- 3 and 7 cleavage that was abrogated by caspase 9 inhibitor that confirmed the extrinsic caspasedependent cell death mechanism. Western-Blot analysis showed an up-regulation of pro-apoptotic proteins Bax and Bad and a downregulation of anti-apoptotic protein Bcl-xL (133). The same team analyzed effects of kaempferol on VEGF expression in ovarian cancer cells. Results show that this flavonol inhibits time-dependently VEGF secretion and angiogenesis. It also down-regulates phosphoERK concomitant with $c-m y c$ and NF- $\kappa \mathrm{B}$ expression through ERK signaling pathway (134). They also developed different kaempferol nanoparticles and have tested their efficiency on cancerous and normal ovarian cells. PEO [poly(ethylene oxide)], PPO [poly(propylene oxide)], PEO poly(ethylene oxide) decreases both ovarian cancer and healthy cell viability. On the opposite (PLGA) [Poly(DL-lactic acid-co-glycolic acid)] exerts selective cytotoxic effect on cancer cells only. However, all kaempferol nanoparticle formulations were able to reduce cancer cell viability better than kaempferol alone (245). Pharmacokinetic in vivo studies performed on human and rats have revealed that kaempferol is mainly absorbed in the small intestine and is metabolized to glucurono and sulfo-conjugated forms in the liver. Results have shown that kaempferol has a very poor bioavailability $(2 \%)$ and that after ingestion of several $\mathrm{mg}$ of kaempferol, it is only detected at nanomolar levels in plasma and it should be emphasized that most in vitro studies were conducted at micromolar concentrations $(132,231,246)$. It has also been showed that kaempferol can be converted into its analog, quercetin (Figure 2) by the enzyme CYP1A1 in rats (247). Although cancer cells are able to eliminate compounds like quercetin, it has been shown by Sesink et al. that kaempferol blocks Bcrp-mediated quercetin efflux by competitive inhibition $(234,248)$. Based on this discovery, it has been shown that kaempferol enhances the effect of cisplatin in ovarian cancer cells and of etoposide in rat models $(249,250)$.

\section{CONCLUSION}

This review has presented the different known chemopreventive and therapeutic agents isolated from D. muscipula. At the present time, more than 15 compounds (Figure 2) have been isolated from D. muscipula, mostly flavonoids, and phenolic compounds. Most of these secondary metabolites are also present in other plants and up to now, only one D. muscipula-specific molecule with therapeutic potential has been isolated from Venus flytrap, diomuscipulone (Figure 2). But this naphthoquinone has not yet been tested for its biological properties like several others compounds as diomuscinone, droserone, 3-chloroplumbagin, and hydroplumbagin 4-O- $\beta$-glucopyranoside or $p$-coumaric acid (Figure 2 ) which are also present in other plants. Many of these anti-cancer compounds present in D. muscipula have been described as NF-кB pathway modulators like plumbagin, ellagic acid, or salicylic acid. The reason is that the NF- $\kappa$ B pathway is an interesting anti-cancer drug target due to its involvement into the development and the progression of many cancers (251-253). However it's important to keep in mind that the NF- $\kappa \mathrm{B}$ pathway is not responsible for all types of cancer and that there are many other pathways and phenomena involved in cancer development and progression that can be the targets for drugs of natural origins $(18,19,28$, 251, 254, 255).

Currently only several compounds like quercetin, salicylic acid, and kaempferol have moved to pharmacokinetic studies and clinical trials (Table 2). All results have shown that these compounds have a very poor bioavailability that can be explained by several reasons. Plant secondary metabolites are often recognized as xenobiotics by the organism and are rapidly detoxified by gut flora or enzymes and eliminated from the organism. Intestinal bacteria are known to metabolize drugs before their absorption by the organism. Some drugs can be directly metabolized by the organism or can be conjugated and transformed into an inactive molecule before reaching their target. However several studies have shown that it is possible that this defense mechanism can lead to the conversion of an inactive molecule into another one

Table 2 | Clinical trials involving natural compounds present in Dionaea muscipula Solander ex Ellis.

\begin{tabular}{|c|c|c|c|c|c|}
\hline Chemical class & Compound & Trial name & Disease & Status & Identifier \\
\hline \multirow[t]{2}{*}{ Phenolic acids } & Ellagic acid & Dietary intervention in follicular lymphoma & Follicular lymphoma & Unknown & NCT00455416 \\
\hline & Ferulic acid & $\begin{array}{l}\text { FLAX FX, A research study of the effects of } \\
\text { flaxseed lignans on colon health }\end{array}$ & Colon cancer & Recruiting & NCT01619020 \\
\hline Flavonoid & & $\begin{array}{l}\text { Sulindac and Plant compounds in preventing colon } \\
\text { cancer }\end{array}$ & Colon cancer & Terminated & NCT00003365 \\
\hline
\end{tabular}

The table was generated by using data available from the website http:// clinicaltrials.gov 
like kaempferol into quercetin. Moreover, it is known that cancer cells use drug resistance mechanisms like ABC transporter efflux pumps to down-regulate intracellular drug levels. It is very important to take theses mechanisms into consideration to understand and develop cancer drugs of natural origins but also all other kinds of drugs. New secondary metabolites generated by the organism during drug metabolism by bacteria, the organism itself, or cancer cells should be identified and taken into consideration. It is also very important to underline that due to the low bioavailability of several of these compounds, they are only present in nanomolar concentration in plasma while in many studies, a concentration in milli or micromolar is used to treat cells in in vitro conditions and to obtain an effect. However, it has been shown that co-treatment of two natural molecules like quercetin and kaempferol and a chemotherapeutic drug like cisplatin or etoposide is more efficient than a single treatment thanks to the ability of the natural compound to block ABC transporters. Low bioavailability and incompletely absorbed compounds are ineffective against metastatic and invasive cancers.

One of the most promising anti-cancer compounds is probably plumbagin. It has been shown that plumbagin induces cell death, affects many hallmarks of cancer, interacts directly with cancer targets like tubulin, inhibits ABC transporters, is well absorbed by the organism and can be present in the organism at a micromolar concentration. We have to underline that plumbagin is used for centuries in traditional medicines and is present in many plants that can explain that plumbagin is more studied than other Venus flytrap compounds.

Most natural compounds isolated from D. muscipula like plumbagin, quercetin, myricetin, ellagic acid, or vanillin have multiple effects and act as anti-cancer drugs with multiple targets on different types of cancers. However, as in many cases, direct drug targets are often unknown and there are several reasons that can explain this situation. Plant secondary metabolites are usually small molecules compared to their protein targets and analytical methods have only been developed recently and this step is usually

\section{REFERENCES}

1. Baguley BC. Multiple drug resistance mechanisms in cancer. Mol Biotechnol (2010) 46: 308-16. doi:10.1007/s12033-0109321-2

2. Liu FS. Mechanisms of chemotherapeutic drug resistance in cancer therapy - a quick review. Taiwan J Obstet Gynecol (2009) 48:23944. doi:10.1016/S1028-4559(09) 60296-5

3. Morens DM, Fauci AS. Emerging infectious diseases in 2012: 20 years after the institute of medicine report. MBio (2012) 3. doi:10. 1128/mBio.00494-12

4. Cragg GM, Newman DJ. Natural products: a continuing source of novel drug leads. Biochim Biophys Acta (2013). 1830:3670-95. doi:10. 1016/j.bbagen.2013.02.008

5. Newman DJ, Cragg GM. Natural products as sources of new drugs over the 30 years from 1981 to 2010. J Nat Prod (2012) 75:311-35. doi:10.1021/np200906s

6. Bourgaud F, Gravot A, Milesi S, Gontier E. Production of plant secondary metabolites: a historical perspective. Plant Sci (2001) 161:839-51. doi:10.1016/ S0168-9452(01)00490-3

7. Craik DJ. Host-defense activities of cyclotides. Toxins (2012) 4:139-56. doi:10.3390/toxins4020139

8. Hartmann T. From waste products to ecochemicals: fifty years research of plant secondary metabolism. Phytochemistry (2007) 68:2831-46. doi:10.1016/j. phytochem.2007.09.017

9. Heinen TE, da Veiga AB. Arthropod venoms and cancer. Toxicon (2011) 57:497-511. doi:10.1016/j. toxicon.2011.01.002

10. Jain D, Kumar S. Snake venom: a potent anticancer agent. Asian Pac

the most challenging, expensive and the most time consuming in the drug development process. On one hand, the development of new methods, techniques, and devices like high-throughput screening but also of new biological discoveries (new organism, interspecies interactions) will lead to new molecule discovery in already known organisms but also in new species (256-260). On the other hand, discovery of new anti-cancer drug targets, new visions, and new approaches of cancer development by biological experiments as for example identification of immediate drug direct protein and nucleic acid targets by Drug Affinity Responsive Target Stability (DARTS) or chemical proteomics (261-263) but also by computational data analysis like molecular docking (264266) and grouping together all these data in databases like STITCH (Search Tool for Interactions of Chemicals) (267) will also allow investigation of new cancer treatments. Moreover, development and screening of known and new derivatives from Venus flytrap but also from other plants will improve specificity and efficiency of these promising therapeutic compounds (255, 268-272).

Data presented here show that Nature can be considered an impressive medicinal cabinet that remains to be entirely discovered, improved and used by researchers to hit the right targets.

\section{ACKNOWLEDGMENTS}

François Gaascht was supported by a fellowship from the European Union (ITN "RedCat" 215009, Interreg IVa project "Corena”). Research at LBMCC is financially supported by the Foundation de Recherche Cancer et Sang, the Recherches Scientifiques Luxembourg association, the Een Haerz fir kriibskrank Kanner association, the Action Lions Vaincre le Cancer association, the European Union (ITN "RedCat" 215009, interreg Iva project “Corena"), and the Télévie Luxembourg. MDie is supported by the National Research Foundation (NRF) by the MEST of Korea for Tumor Microenvironment Global Core Research Center (GCRC) grant [grant number 2012-0001184]; by the Seoul National University Research grant and by the Research Settlement Fund for the new faculty of SNU.

J Cancer Prev (2012) 13:4855-60. doi:10.7314/APJCP.2012.13.10. 4855

11. Namdeo A. (2007). Plant cell elicitation for production of secondary metabolites: a review. Phog Rev (2007) 1:69-79.

12. Schmidt EW, Donia MS, McIntosh JA, Fricke WF, Ravel J. Origin and variation of tunicate secondary metabolites. J Nat Prod (2012) 75:295-304. doi:10.1021/ np200665k

13. Amin AR, Kucuk O, Khuri FR Shin DM. Perspectives for cancer prevention with natural compounds. J Clin Oncol (2009) 27: 2712-25. doi:10.1200/JCO.2008. 20.6235

14. Kreher B, Neszmélyi A, Wagner H. Naphthoquinones from Dionaea muscipula. Phytochemistry (1990) 29:605-6. doi:10. 1016/0031-9422(90)85125-Y
15. Gaascht F, Teiten MH, Schumacher M, Dicato M, Diederich M. Approche végétale dans le traitement des leucémies. Corresp Onco-Hématol (2010) V: 102-8.

16. Gullett NP, Ruhul Amin AR, Bayraktar S, Pezzuto JM, Shin DM, Khuri FR, et al. Cancer prevention with natural compounds. Semin Oncol (2010) 37:258-81. doi:10.1053/j.seminoncol.2010.06. 014

17. Surh YJ. Cancer chemoprevention with dietary phytochemicals. Nat Rev Cancer (2003) 3:768-80. doi: $10.1038 / \mathrm{nrc1} 189$

18. Schumacher M, Kelkel M, Dicato M, Diederich M. Gold from the sea: marine compounds as inhibitors of the hallmarks of cancer. Biotechnol Adv (2011) 29:531-47. doi:10.1016/j.biotechadv.2011.02. 002 
19. Teiten MH, Gaascht F, Dicato M, Diederich M. Targeting the wingless signaling pathway with natural compounds as chemopreventive or chemotherapeutic agents. Curr Pharm Biotechnol (2012) 13:245-54. doi:10.2174/ 138920112798868593

20. Kelkel M, Jacob C, Dicato M, Diederich M. Potential of the dietary antioxidants resveratrol and curcumin in prevention and treatment of hematologic malignancies. Molecules (2010) 15:7035-74. doi:10.3390/molecules15107035

21. Bishayee A, Politis T, Darvesh AS. Resveratrol in the chemoprevention and treatment of hepatocellular carcinoma. Cancer Treat $\operatorname{Rev}$ (2010) 36:43-53. doi:10.1016/ j.ctrv.2009.10.002

22. Kraft TE, Parisotto D, Schempp C, Efferth T. Fighting cancer with red wine? Molecular mechanisms of resveratrol. Crit Rev Food Sci Nutr (2009) 49:782-99. doi:10. 1080/10408390802248627

23. Martin MA, Goya L, Ramos S. Potential for preventive effects of cocoa and cocoa polyphenols in cancer. Food Chem Toxicol (2013) 56:336-51. doi:10.1016/j.fct.2013. 02.020

24. Maskarinec G. Cancer protective properties of cocoa: a review of the epidemiologic evidence. Nutr Cancer (2009) 61:573-9. doi:10.1080/ 01635580902825662

25. Khalil MI, Sulaiman SA. The potential role of honey and its polyphenols in preventing heart diseases: a review. Afri J Tradit Complement Altern Med (2010) 7:315-21.

26. Sawadogo WR, Schumacher M, Teiten $\mathrm{MH}$, Dicato $\mathrm{M}$, Diederich M. Traditional West African pharmacopeia, plants and derived compounds for cancer therapy. Biochem Pharmacol (2012) 84:1225-40. doi:10.1016/j.bcp.2012.07.021

27. Nobili S, Lippi D, Witort E, Donnini M, Bausi L, Mini E, et al. Natural compounds for cancer treatment and prevention. Pharmacol Res (2009) 59:365-78. doi:10. 1016/j.phrs.2009.01.017

28. Orlikova B, Diederich M. Power from the garden: plant compounds as inhibitors of the hallmarks of cancer. Curr Med Chem (2012) 19:2061-87. doi:10.2174/ 092986712800228998

29. Efferth T, Li PC, Konkimalla VS, Kaina B. From traditional Chinese medicine to rational cancer therapy. Trends Mol Med (2007) 13:353-61. doi:10.1016/j.molmed. 2007.07.001

30. Folmer F, Jaspars M, Dicato M, Diederich M. Marine natural products as targeted modulators of the transcription factor NF-kappaB. Biochem Pharmacol (2008) 75:603-17. doi:10.1016/ j.bcp.2007.07.044

31. Senevirathne M, Kim SK. Utilization of seafood processing by-products: medicinal applications. Adv Food Nutr Res (2012) 65:495-512. doi:10.1016/B978-012-416003-3.00032-9

32. Zhou ZF, Guo YW. Bioactive natural products from Chinese marine flora and fauna. Acta Pharmacol Sin (2012) 33:1159-69. doi: 10.1038/aps.2012.110

33. Mayer AM, Gustafson KR. Marine pharmacology in 2005-2006: antitumour and cytotoxic compounds. Eur J Cancer (2008) 44:2357-87. doi:10.1016/j.ejca.2008.07.001

34. Molinski TF, Dalisay DS, Lievens SL, Saludes JP. Drug development from marine natural products. Nat Rev Drug Discov (2009) 8:69-85. doi:10.1038/nrd2487

35. Ellingwood F, Lloyd JU. American Materia Medica, Therapeutics and Pharmacognosy: Developing the Latest Acquired Knowledge of Drugs, and Especially of the Direct Action of Single Drugs Upon Exact Conditions of Disease, with Especial Reference to the Therapeutics of the Plant Drugs of the Americas. Chicago: Ellingwood's therapeutist (1919). $542 \mathrm{p}$

36. Lloyd J, Felter H. King's American Dispensatory. 18th ed. Sandy, OR: Eclectic Medical Publications (1898).

37. Moerman DE. Native American Ethnobotany Database. Portland: Timber Press, Inc (1998). 927 p.

38. Remington JP. The Dispensatory of the United States of America. Philadelphia: Lippincott (1918) 2010 p.

39. Muhammad A, Guerrero-Analco JA, Martineau LC, Musallam L, Madiraju P, Nachar A, et al. Antidiabetic compounds from Sarracenia purpurea used traditionally by the Eeyou Istchee Cree First Nation. J NatProd (2012) 75:1284-8. doi:10. 1021/np3001317

40. Renshaw CJ. Treatment of smallpox by Sarracenia Purpurea. BMJ (1863) 1:127-127. doi:10.1136/ bmj.1.109.127

41. Behera KK, Sahoo S, Mohapatra PC. Medicinal plant resources for bioprospecting and drug development in tribal rich district of Orissa, India. Ethnobot Leafl (2007) 11:106-12.

42. Kayang H, Kharbuli B, Myrboh B, Syiem D. Medicinal plants of Khasi hills of Meghalaya, India. In: Bernáth ENJ, Craker LE, Gardner ZE, editors. III WOCMAP Congress on Medicinal and Aromatic Plants-Volume 1: Bioprospecting and Ethnopharmacology. Chiang Mai: Acta Horticulturae (2003). p. $75-80$.

43. Kumar S. The Medicinal Plants of North-East India. Jodhpur: Scientific Publishers (2002). 212 p.

44. Prasad MNV, Jeeva S. Coal mining and its leachate are potential threats to Nepenthes khasiana Hook. f.(Nepenthaceae) that preys on insects-an endemic plant in North Eastern India. Biol Div Con (2009) 2:29-33.

45. Shin KS, Lee S, Cha BJ. Suppression of phytopathogenic fungi by hexane extract of Nepenthes ventricosa $\mathrm{x}$ maxima leaf. Fitoterapia (2007) 78:585-6. doi:10.1016/ j.fitote.2007.03.020

46. Singh J, Mudgal V. Studies on habitat conditions of a few plants species of medicinal values of Nokrek Biosphere Reserve, Meghalaya. J Non-Timber For Products (1999) 6:4.

47. Volkov AG, Murphy VA, Clemmons JI, Curley MJ, Markin VS. Energetics and forces of the Dionaea muscipula trap closing. J Plant Physiol (2012) 169:55-64. doi:10. 1016/j.jplph.2011.08.003

48. Volkov AG, Harris SL 2nd, Vilfranc CL, Murphy VA, Wooten JD, Paulicin H, et al. Venus flytrap biomechanics: forces in the Dionaea muscipula trap. J Plant Physiol (2013) 170:25-32. doi:10.1016/ j.jplph.2012.08.009

49. Volkov AG, Adesina T, Markin VS, Jovanov E. Kinetics and mechanism of Dionaea muscipula trap closing. Plant Physiol (2008) 146:694-702. doi:10.1104/pp.107. 108241

50. Schulze WX, Sanggaard KW, Kreuzer I, Knudsen AD, Bemm F, Thogersen IB, et al. The protein composition of the digestive fluid from the venus flytrap sheds light on prey digestion mechanisms. Mol Cell Proteomics (2012) 11:1306-19. doi:10.1074/mcp.M112.021006

51. Adlassnig W, Koller-Peroutka M, Bauer S, Koshkin E, Lendl T, Lichtscheidl IK. Endocytotic uptake of nutrients in carnivorous plants. Plant J (2012) 71:303-13.
doi:10.1111/j.1365-313X.2012. 04997.x

52. Krol E, Plachno BJ, Adamec L, Stolarz M, Dziubinska H, Trebacz K. Quite a few reasons for calling carnivores 'the most wonderful plants in the world.' Ann Bot (Lond) (2012) 109:47-64. doi:10. $1093 / \mathrm{aob} / \mathrm{mcr} 249$

53. Scala J, Iott K, Schwab DW, Semersky FE. Digestive secretion of Dionaea muscipula (Venus's Flytrap). Plant Physiol (1969) 44:36771. doi:10.1104/pp.44.3.367

54. Kovacik J, Klejdus B, Repcakova K. Phenolic metabolites in carnivorous plants: inter-specific comparison and physiological studies. Plant Physiol Biochem (2012) 52:21-7. doi:10.1016/j.plaphy.2011.11.007

55. Krolicka A, Szpitter A, Gilgenast E, Romanik G, Kaminski M, Lojkowska E. Induction of naphthoquinone and flavonoid production in Dionaea muscipula and Drosera capensis. Planta Med (2006) 72:137.

56. Nagata T, Ebizuka Y. Medicinal and Aromatic Plants XII. Dordrecht: Springer (2002). $348 \mathrm{p}$.

57. Pakulski G, Budzianowski J. Ellagic acid derivatives and naphthoquinones of Dionaea muscipula from in vitro cultures. Phytochemistry (1996) 41:775-8. doi:10.1016/0031-9422(96) 89675-0

58. Tokunaga T, Takada N, Ueda M. Mechanism of antifeedant activity of plumbagin, a compound concerning the chemical defense in carnivorous plant. Tetrahedron Lett (2004) 45:7115-9. doi:10.1016/j. tetlet.2004.07.094

59. Hsieh Y-J, Lin L-C, Tsai T-H. Determination and identification of plumbagin from the roots of Plumbago zeylanica L. by liquid chromatography with tandem mass spectrometry. J Chromatogr A (2005) 1083:141-5. doi:10.1016/ j.chroma.2005.06.030

60. Bashir A, Abdalla A, Wasfi I, Hassan E, Amiri M, Crabb T. Flavonoids of Limonium axillare. Pharm Biol (1994) 32:366-72. doi: 10.3109/13880209409083017

61. Binder RG, Benson ME, Flath RA. Eight 1, 4-naphthoquinones from Juglans. Phytochemistry (1989) 28:2799-801. doi:10.1016/S00319422(00)98092-0

62. Hedin PA, Collum DH, Langhans VE, Graves CH. Distribution of juglone and related compounds in pecan and their effect on Fusicladium effusum. J Agric 
Food Chem (1980) 28:340-2. doi: 10.1021/jf60228a026

63. Raj G, Kurup R, Hussain AA, Baby S. Distribution of naphthoquinones, plumbagin, droserone, and 5-O-methyl droserone in chitin-induced and uninduced Nepenthes khasiana: molecular events in prey capture. J Exp Bot (2011) 62:5429-36. doi:10.1093/ jxb/err219

64. Aung HH, Chia LS, Goh NK, Chia TF, Ahmed AA, Pare PW, et al. Phenolic constituents from the leaves of the carnivorous plant Nepenthes gracilis. Fitoterapia (2002) 73:445-7. doi:10.1016/ S0367-326X(02)00113-2

65. Kawiak A, Piosik J, Stasilojc G, Gwizdek-Wisniewska A, Marczak $\mathrm{L}$, Stobiecki $\mathrm{M}$, et al. Induction of apoptosis by plumbagin through reactive oxygen speciesmediated inhibition of topoisomerase II. Toxicol Appl Pharmacol (2007) 223:267-76. doi:10.1016/j. taap.2007.05.018

66. Acharya BR, Bhattacharyya B, Chakrabarti G. The natural naphthoquinone plumbagin exhibits antiproliferative activity and disrupts the microtubule network through tubulin binding. Biochemistry (2008) 47:7838-45. doi:10. 1021/bi800730q

67. Hsu YL, Cho CY, Kuo PL, Huang YT, Lin CC. Plumbagin (5-hydroxy-2-methyl-1,4naphthoquinone) induces apoptosis and cell cycle arrest in A549 cells through p53 accumulation via c-Jun $\mathrm{NH} 2$-terminal kinase-mediated phosphorylation at serine 15 in vitro and in vivo. I Pharmacol Exp Ther (2006) 318:484-94. doi:10.1124/jpet.105.098863

68. Sandur SK, Ichikawa H, Sethi G, Ahn KS, Aggarwal BB. Plumbagin (5-hydroxy-2-methyl-1,4naphthoquinone) suppresses NF-kappaB activation and NFkappaB-regulated gene products through modulation of p65 and IkappaBalpha kinase activation, leading to potentiation of apoptosis induced by cytokine and chemotherapeutic agents. J Biol Chem (2006) 281: 17023-33.

69. Li L, Huang J, Xu X, Zhang Y, Cheng K, Yu P. Study on chemical constituents of Drosera peltata var. multisepala. Zhongguo Zhong Yao Za Zhi (2012) 37:222-5.

70. Gu JQ, Graf TN, Lee D, Chai HB, Mi Q, Kardono LB, et al. Cytotoxic and antimicrobial constituents of the bark of Diospyros maritima collected in two geographical locations in Indonesia. J Nat Prod (2004) 67:1156-61. doi:10.1021/ np040027m

71. Lin LC, Yang LL, Chou CJ. Cytotoxic naphthoquinones and plumbagic acid glucosides from Plumbago zeylanica. Phytochemistry (2003) 62:619-22. doi:10. 1016/S0031-9422(02)00519-8

72. Whitson EL, Sun H, Thomas CL, Henrich CJ, Sayers TJ, McMahon JB, et al. Synergistic TRAIL sensitizers from Barleria alluaudii and Diospyros maritima. J Nat Prod (2012) 75:394-9. doi:10. $1021 /$ np200805z

73. Budzianowski J, Budzianowska A, Kromer K. Naphthalene glucoside and other phenolics from the shoot and callus cultures of Drosophyllum lusitanicum. Phytochemistry (2002) 61:421-5. doi:10. 1016/S0031-9422(02)00258-3

74. Bringmann G, Rischer H, Wohlfarth M, Schlauer J, Assi LA. Droserone from cell cultures of Triphyophyllum peltatum (Dioncophyllaceae) and its biosynthetic origin. Phytochemistry (2000) 53:339-43. doi:10.1016/S00319422(99)00543-9

75. Sidhu G, Sankaram A. A new biplumbagin and 3chloroplumbagin from Plumbago zeylanica. Tetrahedron Lett (1971) 12:2385-8. doi:10.1016/S00404039(01)96870-4

76. Likhitwitayawuid K, Kaewamatawong R, Ruangrungsi N, Krungkrai J. Antimalarial naphthoquinones from Nepenthes thorelii. Planta Med (1998) 64:237-41. doi:10.1055/s-2006-957417

77. Miyoshi E, Shizuri Y, Yamamura S. Isolation and structures of diomuscinone and diomuscipulone from Dionaea muscipula. Phytochemistry (1984) 23:2385-7. doi: 10.1016/S0031-9422(00)80563-4

78. Salae A-W, Karalai C, Ponglimanont C, Kanjana-Opas A, Yuenyongsawad S. Naphthalene derivatives from Diospyros wallichii. Can J Chem (2010) 88:922-7. doi:10.1139/V10-084

79. Aguilera-Carbo A, Augur C, Prado-Barragan L, Aguilar C, Favela-Torres E. Extraction and analysis of ellagic acid from novel complex sources. Chem Papers (2008) 62:440-4. doi:10.2478/s11696-008-0042-y

80. Cardona JA, Lee JH, Talcott ST. Color and polyphenolic stability in extracts produced from muscadine grape (Vitis rotundifolia) pomace. J Agric Food Chem (2009) 57:8421-5. doi:10.1021/ jf901840t

81. Huang WY, Zhang HC, Liu WX, Li CY. Survey of antioxidant capacity and phenolic composition of blueberry, blackberry, and strawberry in Nanjing. $J$ Zhejiang Univ Sci B (2012) 13:94-102. doi:10.1631/ jzus.B1100137

82. Pellati F, Bruni R, Righi D, Grandini A, Tognolini M, Pio Prencipe F, et al. Metabolite profiling of polyphenols in a Terminalia chebula Retzius ayurvedic decoction and evaluation of its chemopreventive activity. $J$ Ethnopharmacol (2013) 147: 277-85. doi:10.1016/j.jep.2013.02. 025

83. Edderkaoui M, Odinokova I, Ohno I, Gukovsky I, Go VL, Pandol SJ, et al. Ellagic acid induces apoptosis through inhibition of nuclear factor kappa B in pancreatic cancer cells. World J Gastroenterol (2008) 14:3672-80. doi:10.3748/ wjg. 14.3672

84. Malik A, Afaq S, Shahid M, Akhtar K, Assiri A. Influence of ellagic acid on prostate cancer cell proliferation: a caspasedependent pathway. Asian Pac Trop Med (2011) 4:550-5. doi:10. 1016/S1995-7645(11)60144-2

85. Tan KW, Li Y, Paxton JW, Birch NP, Scheepens A. Identification of novel dietary phytochemicals inhibiting the efflux transporter breast cancer resistance protein (BCRP/ABCG2). Food Chem (2013) 138:2267-74. doi:10.1016/ j.foodchem.2012.12.021

86. Karimi E, Oskoueian E, Hendra R, Oskoueian A, Jaafar HZ. Phenolic compounds characterization and biological activities of Citrus aurantium bloom. Molecules (2012) 17:1203-18. doi:10.3390/ molecules17021203

87. Lai TN, Herent MF, QuetinLeclercq J, Nguyen TB, Rogez $\mathrm{H}$, Larondelle $\mathrm{Y}$, et al. Piceatannol, a potent bioactive stilbene, as major phenolic component in Rhodomyrtus tomentosa. Food Chem (2013) 138:1421-30. doi:10. 1016/j.foodchem.2012.10.125

88. Sultana N, Akhter M, Khatoon Z. Nematicidal natural products from the aerial parts of Rubus niveus. Nat Prod Res (2010) 24:407-15. doi:10.1080/ 14786410802696429

89. Verma S, Singh A, Mishra A. Gallic acid: molecular rival of cancer. Environ Toxicol Pharmacol
(2013) 35:473-85. doi:10.1016/j. etap.2013.02.011

90. Weidner S, Rybarczyk A, Karamac M, Krol A, Mostek A, Grebosz J, et al. Differences in the phenolic composition and antioxidant properties between Vitis coignetiae and Vitis vinifera seeds extracts. Molecules (2013) 18:3410-26. doi: 10.3390/molecules 18033410

91. Chandramohan Reddy T, Bharat Reddy D, Aparna A, Arunasree KM, Gupta G, Achari C, et al. Anti-leukemic effects of gallic acid on human leukemia K562 cells: downregulation of COX-2, inhibition of BCR/ABL kinase and NF-kappaB inactivation. Toxicol In vitro (2012) 26:396-405. doi:10. 1016/j.tiv.2011.12.018

92. León-González AJ, Truchado P, Tomás-Barberán FA, LópezLázaro $\mathrm{M}$, Barradas $\mathrm{MCD}$, Martín-Cordero C. Phenolic acids, flavonols and anthocyanins in Corema album (L.) D. Don berries. J Food Compost Anal (2013) 29:5863. doi:10.1016/j.jfca.2012.10.003

93. Ao C, Li A, Elzaawely AA, Xuan TD, Tawata S. Evaluation of antioxidant and antibacterial activities of Ficus microcarpa L. fil. extract. Food Control (2008) 19:940-8. doi: 10.1016/j.foodcont.2007.09.007

94. Cottle W, Kolattukudy PE. Biosynthesis, deposition, and partial characterization of potato suberin phenolics. Plant Physiol (1982) 69:393-9. doi:10.1104/pp.69.2.393

95. Lirdprapamongkol K, Sakurai $\mathrm{H}$ Kawasaki N, Choo MK, Saitoh Y, Aozuka Y, et al. Vanillin suppresses in vitro invasion and in vivo metastasis of mouse breast cancer cells. Eur J Pharm Sci (2005) 25 57-65. doi:10.1016/j.ejps.2005.01. 015

96. Lirdprapamongkol K, Sakurai H, Suzuki S, Koizumi K, Prangsaengtong O, Viriyaroj A, et al. Vanillin enhances TRAIL-induced apoptosis in cancer cells through inhibition of NF-kappaB activation. In vivo (2010) 24:501-6.

97. Lirdprapamongkol K, Kramb JP, Suthiphongchai T, Surarit R, Srisomsap C, Dannhardt G, et al. Vanillin suppresses metastatic potential of human cancer cells through PI3K inhibition and decreases angiogenesis in vivo. $J$ Agric Food Chem (2009) 57:305563. doi:10.1021/jf803366f

98. Shahidi F, Perera N. Oil and phytochemicals from small fruit seeds. In: Chi-Tang Ho CM, Shahidi F, Contis ET, editors. Nutrition, Functional and Sensory Properties of 
Foods. Cambridge: RSC Publishing (2013). p. 224-30.

99. Hudson EA, Dinh PA, Kokubun T, Simmonds MS, Gescher A. Characterization of potentially chemopreventive phenols in extracts of brown rice that inhibit the growth of human breast and colon cancer cells. Cancer Epidemiol Biomarkers Prev (2000) 9:1163-70.

100. Chen FF, Wang GY, Shi YP. Molecularly imprinted polymer microspheres for solid-phase extraction of protocatechuic acid in Rhizoma homalomenae. J Sep Sci (2011) 34:2602-10. doi:10.1002/ jssc. 201100463

101. Lin HH, Chen JH, Wang CJ. Chemopreventive properties and molecular mechanisms of the bioactive compounds in Hibiscus sabdariffa Linne. Curr Med Chem (2011) 18:1245-54. doi:10.2174/ 092986711795029663

102. Qing ZJ, Yong W, Hui LY, Yong LW, Long LH, Ao DJ, et al. Two new natural products from the fruits of Alpinia oxyphylla with inhibitory effects on nitric oxide production in lipopolysaccharide-activated RAW264.7 macrophage cells. Arch Pharm Res (2012) 35:2143-6. doi:10.1007/s12272-012-1211-7

103. Tang RN, Qu XB, Guan SH, Xu PP, Shi YY, Guo DA. Chemical constituents of Spatholobus suberectus. Chin J Nat Med (2012) 10:32-5. doi:10.3724/SP.J.1009.2012.00032

104. Lin HH, Chen JH, Chou FP, Wang CJ. Protocatechuic acid inhibits cancer cell metastasis involving the down-regulation of Ras/Akt/NF-kappaB pathway and MMP-2 production by targeting RhoB activation. Br J Pharmacol (2011) 162:237-54. doi:10.1111/j. 1476-5381.2010.01022.x

105. Anter J, Romero-Jimenez M, Fernandez-Bedmar Z, VillatoroPulido M, Analla M, AlonsoMoraga A, et al. Antigenotoxicity, cytotoxicity, and apoptosis induction by apigenin, bisabolol, and protocatechuic acid. J Med Food (2011) 14:276-83. doi:10.1089/jmf.2010.0139

106. Scognamiglio M, Esposito A, D’Abrosca B, Pacifico S, Fiumano $\mathrm{V}$, Tsafantakis $\mathrm{N}$, et al. Isolation, distribution and allelopathic effect of caffeic acid derivatives from $\mathrm{Bel}$ lis perennis L. Biochem Syst Ecol (2012) 43:108-13. doi:10.1016/j. bse.2012.02.025

107. Rajendra Prasad N, Karthikeyan A, Karthikeyan S, Reddy BV. Inhibitory effect of caffeic acid on cancer cell proliferation by oxidative mechanism in human HT-1080 fibrosarcoma cell line. Mol Cell Biochem (2011) 349:11-9. doi:10.1007/s11010-010-0655-7

108. Moon MK, Lee YJ, Kim JS, Kang DG, Lee HS. Effect of caffeic acid on tumor necrosis factoralpha-induced vascular inflammation in human umbilical vein endothelial cells. Biol Pharm Bull (2009) 32:1371-7. doi:10.1248/ bpb.32.1371

109. Jaganathan SK. Growth inhibition by caffeic acid, one of the phenolic constituents of honey, in HCT 15 colon cancer cells. ScientificWorldJournal (2012) 2012:372345. doi:10.1100/2012/372345

110. Bouayed J, Rammal H, Dicko A, Younos C, Soulimani R. Chlorogenic acid, a polyphenol from Prunus domestica (Mirabelle), with coupled anxiolytic and antioxidant effects. J Neurol Sci (2007) 262:7784. doi:10.1016/j.jns.2007.06.028

111. Moores R, McDermott DL, Wood T. Determination of chlorogenic acid in coffee. Anal Chem (1948) 20:620-4. doi:10.1021/ac60019a007

112. Zhang B, Yang R, Liu C-Z. Microwave-assisted extraction of chlorogenic acid from flower buds of Lonicera japonica Thunb. Sep PurifTechnol (2008) 62:480-3. doi: 10.1016/j.seppur.2008.02.013

113. Yang J-S, Liu C-W, Ma Y-S, Weng S-W, Tang N-Y, Wu S-H, et al. Chlorogenic acid induces apoptotic cell death in U937 leukemia cells through caspaseand mitochondria-dependent pathways. In vivo (2012) 26:971-8.

114. Graf E. Antioxidant potential of ferulic acid. Free Radic Biol Med (1992) 13:435-48. doi:10.1016/ 0891-5849(92)90184-I

115. Hayat S, Ali B, Ahmad A. Salicylic acid: biosynthesis, metabolism and physiological role in plants. In: Hayat S, Ahmad A, editors. Salicylic Acid: A Plant Hormone. Dordrecht: Springer (2007). p. 1-14

116. Zitta K, Meybohm P, Bein B, Huang Y, Heinrich C, Scholz J, et al. Salicylic acid induces apoptosis in colon carcinoma cells grown invitro: influence of oxygen and salicylic acid concentration. Exp Cell Res (2012) 318:828-34. doi:10. 1016/j.yexcr.2012.02.002

117. Spitz GA, Furtado CM, SolaPenna M, Zancan P. Acetylsalicylic acid and salicylic acid decrease tumor cell viability and glucose metabolism modulating 6phosphofructo-1-kinase structure and activity. Biochem Pharmacol
(2009) 77:46-53. doi:10.1016/j. bcp.2008.09.020

118. Afify Ael M, El-Beltagi HS, ElSalam SM, Omran AA. Biochemical changes in phenols, flavonoids, tannins, vitamin E, beta-carotene and antioxidant activity during soaking of three white sorghum varieties. Asian Pac J Trop Biomed (2012) 2:203-9. doi:10.1016/ S2221-1691(12)60042-2

119. Abaza MS, Al-Attiyah R, Bhardwaj R, Abbadi G, Koyippally M, Afzal M. Syringic acid from Tamarix aucheriana possesses antimitogenic and chemo-sensitizing activities in human colorectal cancer cells. Pharm Biol (2013). doi: 10.3109/13880209.2013.781194. [Epub ahead of print].

120. Kampa M, Alexaki VI, Notas G, Nifli AP, Nistikaki A, Hatzoglou A, et al. Antiproliferative and apoptotic effects of selective phenolic acids on T47D human breast cancer cells: potential mechanisms of action. Breast Cancer Res (2004) 6:R63-74. doi:10.1186/bcr752

121. Muhammad A, Haddad PS, Durst T, Arnason JT. Phytochemical constituents of Sarracenia purpurea L. (pitcher plant). Phytochemistry (2013). doi:10.1016/j.phytochem. 2013.05.015. [Epub ahead of print].

122. Park CH, Chang JY, Hahm ER, Park S, Kim HK, Yang CH. Quercetin, a potent inhibitor against betacatenin/Tcf signaling in SW480 colon cancer cells. Biochem Biophys Res Commun (2005) 328:227-34. doi:10.1016/j.bbrc.2004.12.151

123. Shan BE, Wang MX, Li RQ Quercetin inhibit human SW480 colon cancer growth in association with inhibition of cyclin D1 and survivin expression through Wnt/betacatenin signaling pathway. Cancer Invest (2009) 27:604-12. doi:10.1080/07357900802337191

124. Vidya Priyadarsini R, Senthil Murugan R, Maitreyi S, Ramalingam K, Karunagaran D, Nagini S. The flavonoid quercetin induces cell cycle arrest and mitochondria-mediated apoptosis in human cervical cancer (HeLa) cells through p53 induction and NF-kappaB inhibition. Eur $J$ Pharmacol (2010) 649:84-91. doi:10.1016/j.ejphar.2010.09.020

125. Bishayee K, Ghosh S, Mukheriee A, Sadhukhan R, Mondal J, KhudaBukhsh AR. Quercetin induces cytochrome-c release and ROS accumulation to promote apoptosis and arrest the cell cycle in
G2/M, in cervical carcinoma: signal cascade and drug-DNA interaction. Cell Prolif (2013) 46:15363. doi:10.1111/cpr.12017

126. Kang JW, Kim JH, Song K, Kim SH, Yoon JH, Kim KS. Kaempferol and quercetin, components of Ginkgo biloba extract (EGb 761), induce caspase-3-dependent apoptosis in oral cavity cancer cells. Phytother Res (2010) 24(Suppl 1):S77-82. doi:10.1002/ptr.2913

127. Pakulski G, Budzianowski J. Quercetin and kaempferol glycosides of Dionaea muscipula from in vitro cultures. Planta Med (1996) 62:95-6. doi:10.1055/s-2006-957824

128. Hakkinen SH, Karenlampi SO I, Heinonen M, Mykkanen HM, Torronen AR. Content of the flavonols quercetin, myricetin, and kaempferol in 25 edible berries. $J$ Agric Food Chem (1999) 47:22749. doi:10.1021/jf9811065

129. Oskoueian E, Abdullah N, Ahmad S, Saad WZ, Omar AR, Ho YW. Bioactive compounds and biological activities of Jatropha curcas L. kernel meal extract. Int J Mol Sci (2011) 12:5955-70. doi:10.3390/ ijms12095955

130. Zwolak P, Borja-Cacho D, Phillips P, Dudeja V, Dawra RK, Talukdar $\mathrm{R}$, et al. Myricetin a novel natural antineoplastic agent decreases progression of human pancreatic cancer via inhibition of Akt kinase and Erk pathways. J Surg Res (2008) 144:200-200. doi:10.1016/ j.jss.2007.12.063

131. Sun F, Zheng XY, Ye J, Wu TT, Wang J, Chen W. Potential anticancer activity of myricetin in human T24 bladder cancer cells both in vitro and in vivo. Nutr Cancer (2012) 64:599-606. doi:10. 1080/01635581.2012.665564

132. Calderon-Montano JM, BurgosMoron E, Perez-Guerrero C, Lopez-Lazaro M. A review on the dietary flavonoid kaempferol. Mini Rev Med Chem (2011) 11:298-344. doi:10.2174/138955711795305335

133. Luo H, Rankin GO, Li Z, Depriest L, Chen YC. Kaempferol induces apoptosis in ovarian cancer cells through activating p53 in the intrinsic pathway. Food Chem (2011) 128:513-9. doi:10.1016/j. foodchem.2011.03.073

134. Luo H, Rankin GO, Juliano N, Jiang BH, Chen YC. Kaempferol inhibits VEGF expression and in vitro angiogenesis through a novel ERK-NFkappaB-cMycp21 pathway. Food Chem 
(2012) 130:321-8. doi:10.1016/j. foodchem.2011.07.045

135. Babula P, Adam V, Kizek R, Sladký Z, Havel L. Naphthoquinones as allelochemical triggers of programmed cell death. Environ Exp Bot (2009) 65:330-7. doi:10.1016/ j.envexpbot.2008.11.007

136. Babula P, Mikelova R, Adam V, Kizek R, Havel L, Sladky Z. Using of liquid chromatography coupled with diode array detector for determination of naphthoquinones in plants and for investigation of influence of $\mathrm{pH}$ of cultivation medium on content of plumbagin in Dionaea muscipula. J Chromatogr B Analyt Technol Biomed Life Sci (2006) 842:28-35. doi:10.1016/j.jchromb.2006.05. 009

137. Eilenberg H, Pnini-Cohen S, Rahamim Y, Sionov E, Segal $\mathrm{E}$, Carmeli $\mathrm{S}$, et al. Induced production of antifungal naphthoquinones in the pitchers of the carnivorous plant Nepenthes khasiana. J Exp Bot (2010) 61:91122. doi:10.1093/jxb/erp359

138. Marczak L, Kawiak A, Lojkowska E, Stobiecki M. Secondary metabolites in in vitro cultured plants of the genus Drosera. Phytochem Anal (2005) 16:143-9. doi:10.1002/pca. 833

139. Tilak JC, Adhikari S, Devasagayam TP. Antioxidant properties of Plumbago zeylanica, an Indian medicinal plant and its active ingredient, plumbagin. Redox Rep (2004) 9:219-27. doi:10.1179/135100004225005976

140. Kuo PL, Hsu YL, Cho CY. Plumbagin induces G2-M arrest and autophagy by inhibiting the AKT/mammalian target of rapamycin pathway in breast cancer cells. Mol Cancer Ther (2006) 5:3209-21. doi:10.1158/ 1535-7163.MCT-06-0478

141. Wang CC, Chiang YM, Sung SC, Hsu YL, Chang JK, Kuo PL. Plumbagin induces cell cycle arrest and apoptosis through reactive oxygen species/c-Jun $\mathrm{N}$-terminal kinase pathways in human melanoma A375.S2 cells. Cancer Lett (2008) 259:82-98. doi:10.1016/j.canlet.2007.10.005

142. Gomathinayagam R, Sowmyalakshmi S, Mardhatillah F, Kumar R, Akbarsha MA, Damodaran C. Anticancer mechanism of plumbagin, a natural compound, on nonsmall cell lung cancer cells. Anticancer Res (2008) 28:785-92.

143. Yang SJ, Chang SC, Wen HC, Chen CY, Liao JF, Chang $\mathrm{CH}$.
Plumbagin activates ERK1/2 and Akt via superoxide, $\mathrm{Src}$ and PI3kinase in 3T3-L1 cells. Eur J Pharmacol (2010) 638:21-8. doi:10. 1016/j.ejphar.2010.04.016

144. Hafeez BB, Zhong W, Fischer JW, Mustafa A, Shi X, Meske L, et al. Plumbagin, a medicinal plant (Plumbago zeylanica)-derived 1,4-naphthoquinone, inhibits growth and metastasis of human prostate cancer PC-3Mluciferase cells in an orthotopic xenograft mouse model. Mol Oncol (2013). 7:428-39. doi:10.1016/j.molonc.2012.12.001

145. Sinha S, Pal K, Elkhanany A, Dutta S, Cao Y, Mondal G, et al. Plumbagin inhibits tumorigenesis and angiogenesis of ovarian cancer cells in vivo. Int $J$ Cancer (2013) 132:1201-12. doi:10.1002/ ijc. 27724

146. Thasni KA, Ratheeshkumar T, Rojini G, Sivakumar KC, Nair RS, Srinivas G, et al. Structure activity relationship of plumbagin in BRCA1 related cancer cells. $\mathrm{Mol}$ Carcinog (2013) 52:392-403. doi: $10.1002 / \mathrm{mc} .21877$

147. Lee JH, Yeon JH, Kim H, Roh W, Chae J, Park HO, et al. The natural anticancer agent plumbagin induces potent cytotoxicity in MCF-7 human breast cancer cells by inhibiting a PI-5 kinase for ROS generation. PLoS ONE (2012) 7:e45023. doi:10. 1371/journal.pone.0045023

148. Padhye S, Dandawate P, Yusufi M, Ahmad A, Sarkar FH. Perspectives on medicinal properties of plumbagin and its analogs. Med Res Rev (2012) 32:1131-58. doi:10. 1002/med.20235

149. Sun J, McKallip RJ. Plumbagin treatment leads to apoptosis in human K562 leukemia cells through increased ROS and elevated TRAIL receptor expression. Leuk Res (2011) 35:1402-8. doi:10. 1016/j.leukres.2011.06.018

150. Shukla S, Wu CP, Nandigama K, Ambudkar SV. The naphthoquinones, vitamin $\mathrm{K} 3$ and its structural analogue plumbagin, are substrates of the multidrug resistance linked ATP binding cassette drug transporter ABCG2. Mol Cancer Ther (2007) 6:3279-86. doi:10. 1158/1535-7163.MCT-07-0564

151. Hsieh YJ, Lin LC, Tsai TH. Measurement and pharmacokinetic study of plumbagin in a conscious freely moving rat using liquid chromatography/tandem mass spectrometry. $J$ Chromatogr $B$ Analyt Technol Biomed Life Sci
(2006) 844:1-5. doi:10.1016/j. jchromb.2006.06.024

152. Higa M, Ogihara K, Yogi S. Bioactive naphthoquinone derivatives from Diospyros maritima Blume. Chem Pharm Bull (1998) 46:1189_ 93. doi:10.1248/cpb.46.1189

153. Lattanzio V, Lattanzio VM, Cardinali A. Role of phenolics in the resistance mechanisms of plants against fungal pathogens and insects. Phytochemistry (2006) 661:23-67.

154. Muller-Scharer H, Schaffner U, Steinger T. Evolution in invasive plants: implications for biological control. Trends Ecol Evol (2004) 19:417-22.

155. Wang Y, Siemann E, Wheeler GS, Zhu L, Gu X, Ding J. Genetic variation in anti-herbivore chemical defences in an invasive plant. J Ecol (2012) 100:894-904. doi:10.1111/ j.1365-2745.2012.01980.x

156. Hancock V, Dahl M, Vejborg RM, Klemm P. Dietary plant components ellagic acid and tannic acid inhibit Escherichia col biofilm formation. J Med Microbiol (2010) 59:496-8. doi:10.1099/ jmm.0.013680-0

157. Quave CL, Estevez-Carmona M, Compadre CM, Hobby G, Hendrickson H, Beenken KE, et al. Ellagic acid derivatives from Rubus ulmifolius inhibit Staphylococcus aureus biofilm formation and improve response to antibiotics. PLoS ONE (2012) 7:e28737. doi:10.1371/journal. pone.0028737

158. Umesalma S, Sudhandiran G. Differential inhibitory effects of the polyphenol ellagic acid on inflammatory mediators NF-kappaB, iNOS, COX-2, TNF-alpha, and IL-6 in 1,2-dimethylhydrazineinduced rat colon carcinogenesis. Basic Clin Pharmacol Toxicol (2010) 107:650-5. doi:10.1111/j. 1742-7843.2010.00565.x

159. Wang N, Wang ZY, Mo SL, Loo TY, Wang DM, Luo HB, et al. Ellagic acid, a phenolic compound, exerts anti-angiogenesis effects via VEGFR-2 signaling pathway in breast cancer. Breast Cancer Res Treat (2012) 134:943-55. doi:10. 1007/s10549-012-1977-9

160. Atri N, Sharma SK, Joshi R, Gulati A, Gulati A. Nutritional and neutraceutical composition of five wild culinary-medicinal species of genus pleurotus (higher basidiomycetes) from northwest India. Int $J$ Med Mushrooms (2013) 15:49-56. doi:10.1615/ IntJMedMushr.v15.i1.60
161. Hamedeyazdan S, Fathiazad F, Sharifi S, Nazemiyeh H. Antiproliferative activity of Marrubium persicum extract in the MCF-7 human breast cancer cell line. Asian Pac J Cancer Prev (2012) 13:5843-8. doi: 10.7314/APJCP.2012.13.11.5843

162. Xiao S, Zhang LF, Zhang X, Li SM, Xue FQ. Tracing antibacterial compounds from Acalypha australis Linn. by spectrumeffect relationships and semipreparative high-performance liquid chromatography. J Sep Sci (2013) 36:1667-76. doi:10.1002/jssc.201201202

163. Chanwitheesuk A, Teerawutgulrag A, Kilburn JD, Rakariyatham N. Antimicrobial gallic acid from Caesalpinia mimosoides Lamk. Food Chem (2007) 100:1044-8. doi:10.1016/j.foodchem.2005.11. 008

164. Nguyen DM, Seo DJ, Lee HB I, Kim S, Kim KY, Park RD, et al. Antifungal activity of gallic acid purified from Terminalia nigrovenulosa bark against Fusarium solani. Microb Pathog (2013) 56:8-15. doi:10.1016/j.micpath. 2013.01.001

165. Ho HH, Chang CS, Ho WC, Liao SY, Lin WL, Wang CJ. Gallic acid inhibits gastric cancer cells metastasis and invasive growth via increased expression of RhoB, downregulation of AKT/small GTPase signals and inhibition of NF-kappaB activity. Toxicol Appl Pharmacol (2013) 266:76-85. doi:10.1016/j. taap.2012.10.019

166. Raina K, Rajamanickam S, Deep G, Singh M, Agarwal R, Agarwal C. Chemopreventive effects of oral gallic acid feeding on tumor growth and progression in TRAMP mice. Mol Cancer Ther (2008) 7:1258-67. doi:10. 1158/1535-7163.MCT-07-2220

167. Liang CZ, Zhang X, Li H, Tao YQ, Tao LJ, Yang ZR, et al. Gallic acid induces the apoptosis

of human osteosarcoma cells in vitro and in vivo via the regulation of mitogen-activated protein kinase pathways. Cancer Biother Radiopharm (2012) 27:701-10. doi:10.1089/cbr.2012.1245

168. Hodgson JM, Morton LW, Puddey IB, Beilin LJ, Croft KD. Gallic acid metabolites are markers of black tea intake in humans. Agric Food Chem (2000) 48:227680. doi:10.1021/jf000089s

169. Shahrzad S, Aoyagi K, Winter A, Koyama A, Bitsch I. 
Pharmacokinetics of gallic acid and its relative bioavailability from tea in healthy humans. $J$ Nutr (2001) 131:1207-10.

170. Kaur B, Chakraborty D. Biotechnological and molecular approaches for vanillin production: a review. Appl Biochem Biotechnol (2013) 169:1353-72. doi:10.1007/s12010-012-0066-1

171. Lesage-Meessen L, Lomascolo A, Bonnin E, Thibault JF, Buleon A, Roller M, et al. A biotechnological process involving filamentous fungi to produce natural crystalline vanillin from maize bran. Appl Biochem Biotechnol (2002) 10(2-103):141-53. doi:10. 1385/ABAB:102-103:1-6:141

172. Walton NJ, Narbad A, Faulds C, Williamson G. Novel approaches to the biosynthesis of vanillin. Curr Opin Biotechnol (2000) 11:490-6. doi:10.1016/S09581669(00)00125-7

173. Walton NJ, Mayer MJ, Narbad A. Vanillin. Phytochemistry (2003) 63:505-15. doi:10.1016/ S0031-9422(03)00149-3

174. Boonchird C, Flegel TW. In vitro antifungal activity of eugenol and vanillin against Candida albicans and Cryptococcus neoformans. Can J Microbiol (1982) 28:1235-41. doi:10.1139/m82-184

175. Yemis GP, Pagotto F, Bach S, Delaquis P. Effect of vanillin, ethyl vanillin, and vanillic acid on the growth and heat resistance of Cronobacter species. J Food Prot (2011) 74:2062-9. doi: 10.4315/0362-028X.JFP-11-230

176. Ho K, Yazan LS, Ismail N, Ismail M. Apoptosis and cell cycle arrest of human colorectal cancer cell line HT-29 induced by vanillin. Cancer Epidemiol (2009) 33:155-60. doi:10.1016/j. canep.2009.06.003

177. Beaudry F, Ross A, Lema PP, Vachon P. Pharmacokinetics of vanillin and its effects on mechanical hypersensitivity in a rat model of neuropathic pain. Phytother Res (2010) 24:525-30. doi:10.1002/ptr. 2975

178. Strand LP, Scheline RR. The metabolism of vanillin and isovanillin in the rat. Xenobiotica (1975) 5:49-63. doi:10.3109/ 00498257509056093

179. Tanaka T, Tanaka T, Tanaka M. Potential cancer chemopreventive activity of protocatechuic acid. $J$ Exp Clin Med (2011) 3:27-33.

180. Yip EC, Chan AS, Pang H, Tam YK, Wong YH. Protocatechuic acid induces cell death in HepG2 hepatocellular carcinoma cells through a c-Jun $\mathrm{N}$ terminal kinase-dependent mechanism. Cell Biol Toxicol (2006) 22:293-302. doi:10.1007/s10565006-0082-4

181. Aziz NH, Farag SE, Mousa LA, Abo-Zaid MA. Comparative antibacterial and antifungal effects of some phenolic compounds. Microbios (1998) 93:43-54.

182. Sato Y, Itagaki S, Kurokawa T, Ogura J, Kobayashi M, Hirano T, et al. In vitro and in vivo antioxidant properties of chlorogenic acid and caffeic acid. Int J Pharm (2011) 403:136-8. doi:10.1016/j.ijpharm. 2010.09.035

183. Lee WJ, Zhu BT. Inhibition of DNA methylation by caffeic acid and chlorogenic acid, two common catechol-containing coffee polyphenols. Carcinogenesis (2006) 27:269-77. doi:10.1093/ carcin/bgi206

184. Azuma K, Ippoushi K, Nakayama $\mathrm{M}$, Ito $\mathrm{H}$, Higashio $\mathrm{H}$, Terao J. Absorption of chlorogenic acid and caffeic acid in rats after oral administration. J Agric Food Chem (2000) 48:5496-500. doi:10.1021/ jf000483q

185. Gonthier MP, Verny MA, Besson C, Remesy C, Scalbert A. Chlorogenic acid bioavailability largely depends on its metabolism by the gut microflora in rats. J Nutr (2003) 133:1853-9.

186. Olthof MR, Hollman PC, Katan MB. Chlorogenic acid and caffeic acid are absorbed in humans. J Nutr (2001) 131:66-71.

187. Peppercorn MA, Goldman P. Caffeic acid metabolism by bacteria of the human gastrointestinal tract. $J$ Bacteriol (1971) 108:996-1000.

188. Hulme AC. The isolation of chlorogenic acid from the apple fruit. Biochem J (1953) 53:337-40.

189. Li H, Chen B, Yao S. Application of ultrasonic technique for extracting chlorogenic acid from Eucommia ulmodies Oliv. (E. ulmodies) Ultrason Sonochem (2005) 12:295300. doi:10.1016/j.ultsonch.2004 01.033

190. Stacewicz-Sapuntzakis M, Bowen PE, Hussain EA, Damayanti-Wood BI, Farnsworth NR. Chemical composition and potential health effects of prunes: a functional food? Crit Rev Food Sci Nutr (2001) 41:251-86. doi:10.1080/ 20014091091814

191. Friend J, Reynolds S, Aveyard MA. Phenylalanine ammonia lyase, chlorogenic acid and lignin in potato tuber tissue inoculated with Phytophthora infestans. Physiol Plant Pathol (1973) 3:495507. doi:10.1016/0048-4059(73) 90060-X

192. Hoover K, Alaniz SA, Yee JL, Rocke DM, Hammock BD, Duffey SS. Dietary protein and chlorogenic acid effect on baculoviral disease of noctuid (Lepidoptera: Noctuidae) larvae. Environ Entomol (1998) 27:1264-72.

193. Ikonen A, Tahvanainen J, Roininen $\mathrm{H}$. Chlorogenic acid as an antiherbivore defence of willows against leaf beetles. Entomol Exp Appl (2001) 99:47-54. doi:10. 1046/j.1570-7458.2001.00800.x

194. Leiss KA, Maltese F, Choi YH, Verpoorte R, Klinkhamer PG. Identification of chlorogenic acid as a resistance factor for thrips in chrysanthemum. Plant Physiol (2009) 150:1567-75. doi:10.1104/ pp.109.138131

195. Thurow T, Lee S-O. Effect of chlorogenic acid and neochlorogenic acid on human colon cancer cells. Disc J (2012) 13:86-93.

196. Burgos-Moron E, CalderonMontano JM, Orta ML, Pastor N, Perez-Guerrero C, Austin C, et al. The coffee constituent chlorogenic acid induces cellular DNA damage and formation of topoisomerase I- and II-DNA complexes in cells. J Agric Food Chem (2012). doi:10.1021/jf300999e

197. Rathod MA, Patel D, Das A, Tipparaju SR, Shinde SS, Anderson RF. Inhibition of radical-induced DNA strand breaks by watersoluble constituents of coffee; phenolics and caffeine metabolites. Free Radic Res (2013) 47:480-7. doi:10.3109/10715762. 2013.788167

198. Li ZH, Wang Q, Ruan X, Pan CD, Jiang DA. Phenolics and plant allelopathy. Molecules (2010) 15:8933-52 doi:10.3390/molecules15128933

199. Palacio L, Cantero JJ, Cusido RM, Goleniowski ME. Phenolic compound production in relation to differentiation in cell and tissue cultures of Larrea divaricata (Cav.). Plant Sci (2012) 19(3-194):1-7. doi:10.1016/j.plantsci.2012.05.007

200. Rasmussen JA, Einhellig FA. Synergistic inhibitory effects of p-coumaric and ferulic acids on germination and growth of grain sorghum. J Chem Ecol (1977) 3:197-205. doi:10.1007/BF00994146

201. Smith BG, Harris PJ. Ferulic acid is esterified to glucuronoarabinoxylans in pineapple cell walls. Phytochemistry (2001) 56:513-9. doi:10. 1016/S0031-9422(00)00401-5

202. Zhao Z, Moghadasian MH. Chemistry, natural sources, dietary intake and pharmacokinetic properties of ferulic acid: a review. Food Chem (2008) 109:691-702. doi:10.1016/j.foodchem.2008.02. 039

203. Srinivasan M, Sudheer AR, Pillai KR, Kumar PR, Sudhakaran PR, Menon VP. Influence of ferulic acid on gamma-radiation induced DNA damage, lipid peroxidation and antioxidant status in primary culture of isolated rat hepatocytes. Toxicology (2006) 228:249-58. doi: 10.1016/j.tox.2006.09.004

204. Baskaran N, Manoharan S, Balakrishnan S, Pugalendhi P. Chemopreventive potential of ferulic acid in 7,12dimethylbenz $[a]$ anthraceneinduced mammary carcinogenesis in Sprague-Dawley rats. Eur J Pharmacol (2010) 637:22-9. doi:10.1016/j.ejphar.2010.03.054

205. Alias LM, Manoharan S, Vellaichamy L, Balakrishnan S, Ramachandran CR. Protective effect of ferulic acid on 7,12-dimethylbenz[a] anthraceneinduced skin carcinogenesis in Swiss albino mice. Exp Toxicol Pathol (2009) 61:205-14. doi:10.1016/j.etp.2008.09.001

206. Janicke B, Hegardt C, Krogh M, Onning G, Akesson B, Cirenajwis HM, et al. The antiproliferative effect of dietary fiber phenolic compounds ferulic acid and $\mathrm{p}$ coumaric acid on the cell cycle of Caco-2 cells. Nutr Cancer (2011) 63:611-22. doi:10.1080/01635581. 2011.538486

207. Maurya DK, Devasagayam TP. Ferulic acid inhibits gamma radiation-induced DNA strand breaks and enhances the survival of mice. Cancer Biother Radiopharm (2013) 28:51-7. doi:10.1089/cbr.2012.1263

208. Li W, Guo J, Tang Y, Wang H, Huang M, Qian D, et al. Pharmacokinetic comparison of ferulic acid in normal and blood deficiency rats after oral administration of Angelica sinensis, Ligusticum chuanxiong and their combination. Int J Mol Sci (2012) 13:358397. doi:10.3390/ijms13033583

209. An C, Mou Z. Salicylic acid and its function in plant immunity. $J$ Integr Plant Biol (2011) 53:41228. doi:10.1111/j.1744-7909.2011. 01043.x 
210. Durner J, Shah J, Klessig DF. Salicylic acid and disease resistance in plants. Trends Plant Sci (1997) 2:266-74. doi:10.1016/ S1360-1385(97)86349-2

211. Fuster V, Sweeny JM. Aspirin: a historical and contemporary therapeutic overview. Circulation (2011) 123:768-78. doi:10.1161/ CIRCULATIONAHA.110.963843

212. Raskin I. Role of salicylic acid in plants. Annu Rev Plant Biol (1992) 43:439-63. doi:10.1146/ annurev.pp.43.060192.002255

213. Vlot AC, Dempsey DA, Klessig DF. Salicylic acid, a multifaceted hormone to combat disease. Annu Rev Phytopathol (2009) 47:177-206. doi:10.1146/annurev. phyto.050908.135202

214. Sung B, Pandey MK, Ahn KS, Yi T, Chaturvedi MM, Liu M, et al. Anacardic acid (6-nonadecyl salicylic acid), an inhibitor of histone acetyltransferase, suppresses expression of nuclear factorkappaB-regulated gene products involved in cell survival, proliferation, invasion, and inflammation through inhibition of the inhibitory subunit of nuclear factor-kappaBalpha kinase, leading to potentiation of apoptosis. Blood (2008) 111:4880-91.

215. Rothwell PM, Wilson M, Elwin CE, Norrving B, Algra A, Warlow CP, et al. Long-term effect of aspirin on colorectal cancer incidence and mortality: 20-year follow-up of five randomised trials. Lancet (2010) 376:1741-50. doi:10.1016/ S0140-6736(10)61543-7

216. Treutter D. Significance of flavonoids in plant resistance: a review. Environ Chem Lett (2006) 4:147-57. doi:10.1007/s10311-006-0068-8

217. Krolicka A, Szpitter A, Gilgenast E, Romanik G, Kaminski M, Lojkowska E. Stimulation of antibacterial naphthoquinones and flavonoids accumulation in carnivorous plants grown in vitro by addition of elicitors. Enzyme Microb Technol (2008) 42:21621. doi:10.1016/j.enzmictec.2007. 09.011

218. Lowry JB, Cook N, Wilson RD. Flavonol glycoside distribution in cultivars and hybrids of Leucaena leucocephala. J Sci Food Agric (1984) 35:401-7. doi:10.1002/jsfa. 2740350407

219. Meckelmann SW, Riegel DW, Van Zonneveld MJ, Rios L, Pena K, Ugas R, et al. Compositional characterization of native Peruvian chili peppers (Capsicum spp.). J
Agric Food Chem (2013) 61:253037. doi:10.1021/jf304986q

220. Stolarczyk M, Piwowarski JP, Granica S, Stefanska J, Naruszewicz M, Kiss AK. Extracts from Epilobium sp. herbs, their components and gut microbiota metabolites of Epilobium Ellagitannins, Urolithins, inhibit hormonedependent prostate cancer cells(LNCaP) proliferation and PSA secretion. Phytother Res (2013). doi:10.1002/ptr.4941. [Epub ahead of print].

221. Tlili N, Elfalleh W, Saadaoui E, Khaldi A, Triki S, Nasri N. The caper (Capparis L.): ethnopharmacology, phytochemical and pharmacological properties. Fitoterapia (2011) 82:93-101. doi:10.1016/j.fitote.2010.09.006

222. Lv J, Yu L, Lu Y, Niu Y, Liu L, Costa J, et al. Phytochemical compositions, and antioxidant properties, and antiproliferative activities of wheat flour. Food Chem (2012) 135(2):325-31. doi:10.1016/j.foodchem.2012.04. 141

223. Weston LA, Mathesius U. Flavonoids: their structure, biosynthesis and role in the rhizosphere, including allelopathy. J Chem Ecol (2013) 39:283-97. doi:10.1007/s10886-013-0248-5

224. Murakami A, Ashida H, Terao J. Multitargeted cancer prevention by quercetin. Cancer Lett (2008) 269:315-25. doi:10.1016/j. canlet.2008.03.046

225. Boly R, Gras T, Lamkami T, Guissou P, Serteyn D, Kiss R, et al. Quercetin inhibits a large panel of kinases implicated in cancer cell biology. Int J Oncol (2011) 38:83342. doi:10.3892/ijo.2010.890

226. Granado-Serrano AB, Martin MA, Bravo L, Goya L, Ramos S. Quercetin induces apoptosis via caspase activation, regulation of Bcl-2, and inhibition of PI-3kinase/Akt and ERK pathways in a human hepatoma cell line (HepG2). J Nutr (2006) 136:271521.

227. Chuang-Xin L, Wen-Yu W, Yao C, Xiao-Yan L, Yun Z. Quercetin enhances the effects of 5-fluorouracil-mediated growth inhibition and apoptosis of esophageal cancer cells by inhibiting NF-kappaB. Oncol Lett (2012) 4:775-8.

228. Spagnuolo C, Cerella C, Russo M, Chateauvieux S, Diederich M, Russo GL. Quercetin downregulates Mcl-1 by acting on mRNA stability and protein degradation.
Br J Cancer (2011) 105:221-30. doi:10.1038/bjc.2011.229

229. Ekstrom AM, Serafini M, Nyren O, Wolk A, Bosetti C, Bellocco R. Dietary quercetin intake and risk of gastric cancer: results from a population-based study in Sweden. Ann Oncol (2011) 22:438-43. doi:10.1093/annonc/mdq390

230. Ferry DR, Smith A, Malkhandi J, Fyfe DW, deTakats PG, Anderson $\mathrm{D}$, et al. Phase I clinical trial of the flavonoid quercetin: pharmacokinetics and evidence for in vivo tyrosine kinase inhibition. Clin Cancer Res (1996) 2 659-68.

231. Barve A, Chen C, Hebbar V, Desiderio J, Saw CL, Kong AN. Metabolism, oral bioavailability and pharmacokinetics of chemopreventive kaempferol in rats. Biopharm Drug Dispos (2009) 30:35665. doi:10.1002/bdd.677

232. Manach C, Morand C, Crespy V, Demigne C, Texier O, Regerat F, et al. Quercetin is recovered in human plasma as conjugated derivatives which retain antioxidant properties. FEBS Lett (1998) 426:331-6. doi:10.1016/ S0014-5793(98)00367-6

233. Manach C, Morand C, Texier O, Favier ML, Agullo G, Demigne $\mathrm{C}$, et al. Quercetin metabolites in plasma of rats fed diets containing rutin or quercetin. J Nutr (1995) 125:1911-22.

234. Sesink AL I, Arts C, de Boer VC, Breedveld P, Schellens JH, Hollman PC, et al. Breast cancer resistance protein (Bcrp1/Abcg2) limits net intestinal uptake of quercetin in rats by facilitating apical efflux of glucuronides. Mol Pharmacol (2005) 67:1999-2006. doi:10. 1124/mol.104.009753

235. Tian M, Bi W, Row KH. Simultaneous extraction and separation of flavonols and flavones from Chamaecyparis obtusa by multi-phase extraction using an ionic liquid-modified microsphere polymer. Phytochem Anal (2012) 23:576-81. doi:10.1002/pca.2357

236. Huang MT, Wood AW, Newmark HL, Sayer JM, Yagi H, Jerina DM, et al. Inhibition of the mutagenicity of bay-region diol-epoxides of polycyclic aromatic hydrocarbons by phenolic plant flavonoids. Carcinogenesis (1983) 4:1631-7. doi: $10.1093 / \mathrm{carcin} / 4.12 .1631$

237. Morales P, Haza AI. Selective apoptotic effects of piceatannol and myricetin in human cancer cells. J Appl Toxicol (2012) 32:986-93. doi:10.1002/jat.1725
238. Shiomi K, Kuriyama I, Yoshida H, Mizushina Y. Inhibitory effects of myricetin on mammalian DNA polymerase, topoisomerase and human cancer cell proliferation. Food Chem (2013) 139:910-8. doi:10.1016/j.foodchem.2013.01. 009

239. Phillips PA, Sangwan V, BorjaCacho D, Dudeja V, Vickers SM, Saluja AK. Myricetin induces pancreatic cancer cell death via the induction of apoptosis and inhibition of the phosphatidylinositol 3-kinase (PI3K) signaling pathway. Cancer Lett (2011) 308:181-8. doi:10.1016/j.canlet

240. Choi SJ, Shin SC, Choi JS. Effects of myricetin on the bioavailability of doxorubicin for oral drug delivery in rats: possible role of CYP3A4 and P-glycoprotein inhibition by myricetin. Arch Pharm Res (2011) 34:309-15. doi:10. 1007/s12272-011-0217-x

241. Li C, Lim SC, Kim J, Choi JS. Effects of myricetin, an anticancer compound, on the bioavailability and pharmacokinetics of tamoxifen and its main metabolite, 4-hydroxytamoxifen, in rats. Eur J Drug Metab Pharmacokinet (2011) 36:175-82. doi:10.1007/ s13318-011-0036-y

242. Chen ND, Chen NF, Chen CW, Zhang L. Separation and structure elucidation of a new homoflavanol derivative from Pteridium aquilinum (L.) Kuhn. Nat Prod Res (2013). doi:10.1080/14786419. 2012.761618. [Epub ahead of print].

243. Tan C, Wang Q, Luo C, Chen S, Li Q, Li P. Yeast \& \#945;-glucosidase inhibitory phenolic compounds isolated from Gynura medica leaf. Int J Mol Sci (2013) 14:2551-8. doi:10.3390/ijms14022551

244. Chen AY, Chen YC. A review of the dietary flavonoid, kaempferol on human health and cancer chemoprevention. Food Chem (2013) 138:2099-107. doi:10. 1016/j.foodchem.2012.11.139

245. Luo H, Jiang B, Li B, Li Z, Jiang BH, Chen YC. Kaempferol nanoparticles achieve strong and selective inhibition of ovarian cancer cell viability. Int $J$ Nanomedicine (2012) 7:3951-9. doi:10.2147/IJN. S33670

246. Li G, Zeng X, Xie Y, Cai Z, Moore JC, Yuan $X$, et al. Pharmacokinetic properties of isorhamnetin, kaempferol and quercetin after oral gavage of total flavones of Hippophae rhamnoides $\mathrm{L}$. in rats using a UPLC-MS method. Fitoterapia 
(2012) 83:182-91. doi:10.1016/j. fitote.2011.10.012

247. Silva ID, Rodrigues AS, Gaspar J, Maia R, Laires A, Rueff J. Involvement of rat cytochrome $1 \mathrm{~A} 1$ in the biotransformation of kaempferol to quercetin: relevance to the genotoxicity of kaempferol. Mutagenesis (1997) 12:383-90. doi:10.1093/mutage/12.5.383

248. An G, Gallegos J, Morris ME. The bioflavonoid kaempferol is an Abcg2 substrate and inhibits Abcg2-mediated quercetin efflux. Drug Metab Dispos (2011) 39: 426-32. doi:10.1124/dmd.110. 035212

249. Li C, Li X, Choi JS. Enhanced bioavailability of etoposide after oral or intravenous administration of etoposide with kaempferol in rats. Arch Pharm Res (2009) 32:133-8. doi:10.1007/s12272-009-1127-z

250. Luo H, Daddysman MK, Rankin GO, Jiang BH, Chen YC. Kaempferol enhances cisplatin's effect on ovarian cancer cells through promoting apoptosis caused by down regulation of cMyc. Cancer Cell Int (2010) 10:16. doi:10.1186/1475-2867-10-16

251. Baud V, Karin M. Is NF-kappaB a good target for cancer therapy? Hopes and pitfalls. Nat Rev Drug Discov (2009) 8:33-40. doi: $10.1038 / \mathrm{nrd} 2781$

252. DiDonato JA, Mercurio F, Karin M. NF-kappaB and the link between inflammation and cancer. Immunol Rev (2012) 246:379-400. doi:10.1111/j.1600-065X.2012. 01099.x

253. Dolcet X, Llobet D, Pallares J, Matias-Guiu X. NF-kB in development and progression of human cancer. Virchows Arch (2005)
446:475-82. doi:10.1007/s00428005-1264-9

254. Delhalle S, Duvoix A, Schnekenburger M, Morceau F, Dicato M, Diederich M. An introduction to the molecular mechanisms of apoptosis. Ann NY Acad Sci (2003) 1010:1-8. doi:10.1196/ annals.1299.001

255. Hanahan D, Weinberg RA. Hallmarks of cancer: the next generation. Cell (2011) 144:646-74. doi:10.1016/j.cell.2011.02.013

256. Gray AI, Igoli JO, Edrada-Ebel R. Natural products isolation in modern drug discovery programs. In: Natural Products Isolation. Dordrecht: Springer (2012). p. 515-34.

257. Li JW, Vederas JC. Drug discovery and natural products: end of an era or an endless frontier? Science (2009) 325:161-5. doi:10. 1126/science. 1168243

258. Mora C, Tittensor DP, Adl S, Simpson AG, Worm B. How many species are there on Earth and in the ocean? PLoS Biol (2011) 9:e1001127. doi:10.1371/journal. pbio. 1001127

259. Quinn RJ. Basics and principles for building natural product-based libraries for HTS. Chem Genomics (2012):87.

260. Zerikly M, Challis GL. Strategies for the discovery of new natural products by genome mining. Chembiochem (2009) 10:625-33. doi:10.1002/cbic.200800389

261. Lomenick B, Olsen RW, Huang J. Identification of direct protein targets of small molecules. ACS Chem Biol (2011) 6:34-46. doi:10.1021/ cb100294v

262. Rix U, Superti-Furga G. Target profiling of small molecules by chemical proteomics. Nat Chem
Biol (2009) 5:616-24. doi:10.1038/ nchembio. 216

263. Roti G, Stegmaier K. Genetic and proteomic approaches to identify cancer drug targets. $\mathrm{Br} \mathrm{J}$ Cancer (2012) 106:254-61. doi:10.1038/ bjc. 2011.543

264. Chen L, Morrow JK, Tran HT, Phatak SS, Du-Cuny L, Zhang S. From laptop to benchtop to bedside: structure-based drug design on protein targets. Curr Pharm Des (2012) 18:1217-39. doi:10.2174/ 138161212799436386

265. Mihasan M. What in silico molecular docking can do for the 'bench-working biologists'. J Biosci (2012) 37:1089-95. doi:10.1007/ s12038-012-9273-8

266. Ou-Yang SS, Lu JY, Kong XQ, Liang ZJ, Luo C, Jiang H. Computational drug discovery. Acta Pharmacol Sin (2012) 33:1131-40. doi 10.1038/aps

267. Kuhn M, Szklarczyk D, Franceschini A, von Mering C, Jensen LJ, Bork P. STITCH 3: zooming in on protein-chemical interactions. Nucleic Acids Res (2012) 40 D876-80. doi:10.1093/nar/ gkr1011

268. Beutler JA. Natural Products as Tools for Discovering New Cancer Targets. In: Natural Products and Cancer Drug Discovery. Dordrecht: Springer (2013). p. 213-37.

269. Chiaradonna F, Moresco RM, Airoldi C, Gaglio D, Palorini R, Nicotra F, et al. From cancer metabolism to new biomarkers and drug targets. Biotechno Adv (2012) 30:30-51. doi:10.1016/ j.biotechadv.2011.07.006

270. Folger O, Jerby L, Frezza C, Gottlieb E, Ruppin E, Shlomi T. Predicting selective drug targets in cancer through metabolic networks. Mol Syst Biol (2011) 7:501. doi:10.1038/msb.2011.35

271. Overington JP,Al-Lazikani B, Hopkins AL. How many drug targets are there? Nat Rev Drug Discov (2006) 5:993-6. doi:10.1038/ nrd2199

272. Patel MN, Halling-Brown MD, Tym JE, Workman P, Al-Lazikani B. Objective assessment of cancer genes for drug discovery. Nat Rev Drug Discov (2013) 12:35-50. doi:10.1038/nrd3913

Conflict of Interest Statement: 'The authors declare that the research was conducted in the absence of any commercial or financial relationships that could be construed as a potential conflict of interest.

Received: 02 April 2013; paper pending published: 30 April 2013; accepted: 24 July 2013; published online: 20 August 2013.

Citation: Gaascht F, Dicato $M$ and Diederich M (2013) Venus flytrap (Dionaea muscipula Solander ex Ellis) contains powerful compounds that prevent and cure cancer. Front. Oncol. 3:202. doi: 10.3389/fonc. 2013.00202

This article was submitted to Cancer Molecular Targets and Therapeutics, a section of the journal Frontiers in Oncology. Copyright (C) 2013 Gaascht, Dicato and Diederich. This is an openaccess article distributed under the terms of the Creative Commons Attribution License (CC BY). The use, distribution or reproduction in other forums is permitted, provided the original author(s) or licensor are credited and that the original publication in this journal is cited, in accordance with accepted academic practice. No use, distribution or reproduction is permitted which does not comply with these terms. 